Int. J. Dev. Biol. 55: 511-525

doi: $10.1387 / \mathrm{ijdb} .103243 \mathrm{eo}$

\title{
Fibronectin and tenascin-C: accomplices in vascular morphogenesis during development and tumor growth
}

\author{
ELLEN VAN OBBERGHEN-SCHILLING *,1,2, RICHARD P. TUCKER ${ }^{3}$, FALK SAUPE ${ }^{4}$, \\ ISABELLE GASSER ${ }^{4}$, BOTOND CSEH ${ }^{1,2}$, GERTRAUD OREND ${ }^{*, 4,5,6}$
}

\begin{abstract}
${ }^{1}$ CNRS UMR6543, IBDC, Nice, France, ${ }^{2}$ University of Nice-Sophia Antipolis, Nice, France, ${ }^{3}$ Cell Biology and Human Anatomy, University of California at Davis, USA, ${ }^{4}$ Inserm U682, Strasbourg, France, ${ }^{5}$ University of Strasbourg, UMRS682, Strasbourg, France and ${ }^{6}$ Department of Molecular Biology, CHRU Strasbourg, Strasbourg, France
\end{abstract}

\begin{abstract}
In addition to soluble factors, the extracellular matrix (ECM) also plays a vital role in normal vasculogenesis and in the pathological angiogenesis of many disease states. Here we will review what is known about the role of the ECM molecules fibronectin and tenascin-C in the vasculature and highlight a potential collaborative interplay between these molecules in developmental and tumorigenic angiogenesis. We will address the evolution of these modular proteins, their cellular interactions and how they become assembled into an insoluble matrix that impacts the assembly of other ECM proteins and the bioavailability of pro-angiogenic factors. The role of fibronectin and tenascin- $C$ networks in tumor angiogenesis and metastasis will be described. We will elaborate on lessons learned about their role in vessel function from the functional ablation or the ectopic expression of both molecules. We will also elaborate on potential mechanisms of how fibronectin and tenascin- $\mathrm{C}$ affect cell adhesion and signaling that are relevant to angiogenesis.
\end{abstract}

KEYWORDS: tumor angiogenesis, matrix assembly, fibronectin, tenascin- $C$

\section{Introduction}

Cells and extracellular matrix (ECM) form tissues, and collections of tissues form organs. In the organism differentorgans act together through blood and lymphatic vessels. Solid tumors resemble organs that are structurally and functionally abnormal. They contain multiple cell types and ECM components and develop through complex interactions between these different components using processes that often resemble those used by developing organs (reviewed in Egeblad et al., 2010). It is long known that tumors need to turn on angiogenesis in order to grow more than a few millimeters in diameter. Tumors have developed several strategies to trigger the so called "angiogenic switch" in order to develop a connection to the hemapoietic and lymphatic vasculature which is believed to be essential for nourishment and oxygenation. Connections to the vasculature also present pathways for motile cancer cells to travel to distant organs to seed metastasis.

In the initial concept of sprouting angiogenesis, largely supported by angiogenesis observed in tumor xenograft experiments, tumors secrete factors that stimulate the process of the outgrowth of new blood vessels from preexisting vessels (Risau, 1997). The development of new vasculature by angiogenesis occurs in two stages. First, a dense, immature, evenly spaced network of new vessels develops by recursive sprouting and fusion of sprouts. Second, the network is remodeled into a hierarchically spaced network by adaptive pruning events and blood flow. How vessel branching is regulated at the molecular level is a matter of debate. Whether the tip cell represents the default state or is actively induced is not clear. At least it is known that VEGFR2, Wnt and notch signaling

Abbreviationsused in thispaper: $\alpha \mathrm{TM}$, alpha tropomyosin; DKK, dickkopf; $\mathrm{E}$, embryonic day; ECM, extracellular matrix; EDA, extra domain A; EDB, extra domain B; EDNRA (B), endothelin receptor type A (B); ET1, endothelin 1; FAK, focal adhesion kinase; FGF, fibroblast growth factor; Id2, inhibitor of differentiation 2; ILK, integrin-linked kinase; JNK, c-Jun N-terminal kinase; LPA, lysophosphatidic acid; MEK, mitogen-activated protein kinase kinase; MMP, matrix metalloproteinase; MMTV, mouse mammary tumor virus; PDGFR, platelet-derived growth factor receptor; PI3K, phosphoinositide 3-kinase; PLCy, phospholipase C gamma; RT2, Rip1Tag2, SV40 T antigen induced insulinoma; TFG $\beta 1$, transforming growth factor beta 1;VEGF, vascular endothelial growth factor; VM, vasculogenic mimicry.

\footnotetext{
*Address correspondence to: Ellen Van Obberghen-Schilling. CNRS UMR6543, Centre A. Lacassagne, 33 Ave de Valombrose, 06189 Nice, France. Fax: +33 (0)492.03.1235. e-mail: vanobber@unice.fr - web: http://www.unice.fr/ibdc/ Gertraud Orend. INSERM UMR-S682, 3 Avenue Molière, 67200 Strasbourg, France. Fax: 33 (0)388.26.3538. e-mail: gertraud.orend@inserm.u-strasbg.fr - web: http://u682-inserm.u-strasbg.fr
} 
are involved in tip cell organization (Bentley et al., 2008). Apart from sprouting angiogenesis, there are several other mechanisms of tumor vascularization, including intussusceptive angiogenesis, vessel co-option, and recruitment of endothelial progenitor cells. In addition, lymphangiogenesis and vasculogenic mimicry are involved in the formation of the tumor microcirculation (Dome et al., 2007; Hillen and Griffioen, 2007; Kucera et al., 2009).

Much emphasis has been placed on the role of angiogenic cytokines such as vascular endothelial growth factor (VEGF) in endothelial cell biology. However, considerable evidence indicates that the matrix is equally important in vessel homeostasis and remodeling. Its role at the molecular level is still poorly understood. ECM proteins provide instructive signals to cells during development, homeostasis and in disease states. The ECM can regulate cell and tissue behavior by serving as a structural network as well as initiating biochemical signaling cascades in cells through interactions with a number of specialized transmembrane ECM receptors such as integrins (reviewed in Erler and Weaver, 2009). Emerging evidence indicates that distinct ECM molecules act in concert to elicit their biological effects. Thus, deciphering the coordinated action of ECM proteins is key to understanding how the ECM network can support normal vascular function and influence the tumor microenvironment to promote angiogenesis.

Fibronectin is a large multi-domain ECM glycoprotein with a fundamental role in blood vessel morphogenesis during embryonic development and pathological angiogenesis. Since the first investigation of fibronectin distribution by Linder and collaborators in chick embryos (Linder et al., 1975), countless studies have documented its elevated expression at sites of tissue remodeling, organogenesis and in numerous disease states. Whereas fibronectin is strongly expressed around developing blood vessels during embryogenesis (Peters and Hynes, 1996), its expression is barely detectable in the normal adult vasculature (ffrenchConstant and Hynes, 1989; Peters et al., 1996). Re-expression of fibronectin occurs during pathological angiogenesis in various diseases such as cancer, late stage artherosclerosis and in blinding ocular conditions (Astrof and Hynes, 2009; Neri and Bicknell, 2005; Pedretti et al., 2009, 2010; Roy et al., 1996, and references therein).

Fibronectin is commonly classified into two forms, plasma fibronectin ( $p$-fibronectin), a soluble form produced by hepatocytes that circulates in blood at high concentrations, and cellular fibronectin (c-fibronectin) produced in tissues where it is incorporated in a fibilllar matrix. c-Fibronectin differs from $\mathrm{p}$-fibronectin by the presence of additional domains, including the highly conserved fibronectin type III "extra" domains B (EDB) and/or A (EDA), that arise from alternative splicing of the pre-mRNA. (Fig. 1, ffrenchConstant and Hynes, 1989; Peters et al., 1996; White et al., 2008,
Fig. 1. Domain structure of fibronectin and tenascin- $C$ and potential binding partners. (A) Fibronectin is a dimeric protein of 240-270KDa, composed of 2 similar or identical monomers joined by a pair of disulfide bonds near the C terminus. Each monomer is organized into type I, type II and type III repeats (FN I-III). Extra Domains $B(B)$ and $A(A)$ correspond to type III repeats. Alternate splicing at a third site (V) gives rise to inserts of variable length (up to 5 in humans) that are nearly always included in c-fibronectin. Heparin-binding domains (Hep) I-III and binding domains for cellular receptors, ECM components, enzymes and growth factors are indicated. Multiple cellular binding sites for fibronectin contribute to angiogenesis (reviewed in Avraamides et al., 2008; Hynes, 2007). Most notably, the tri-peptide motifArg-GlyAsp (RGD) located in the 10th FN type III repeat (FN III-10) is the site of binding to $\alpha 5 \beta 1$ integrin, as well as $\alpha v$-based integrins (Leiss et al., 2008; Pankov and Yamada, 2002) including $\alpha v \beta 3$ and $\alpha v \beta 5$, which are all currently targeted in anti-angiogenic strategies (Desgrosellier and Cheresh, 2010). The asterisks correspond to sites of mutations FN1 identified in patients with glomerulopathy and fibronectin deposits (GFND) (Castelletti et al., 2008). Integrin $\alpha 5 \beta 1$ binding to the RGD motif in FN III-10 requires the synergy region in the 9th FN type III repeat (Danen et al., 1995). (B)

Tenascin-C is a modular molecule composed of an oligomerization domain, EGF-L and FN type III (constant and alternate) repeats, and a fibrinogen like domain (see Orend and Chiquet-Ehrismann, 2006). Binding sites for interacting molecules are indicated. CALEB, chicken acidic leucine-rich EGF like domain containing brain protein, EGFR, epidermal growth factor receptor, NaN, sodium channel subunit $\beta 2$, RPTP $\beta$, protein tyrosine phosphatase $\beta$, TLR4, toll like receptor 4 .

\section{A Fibronectin}

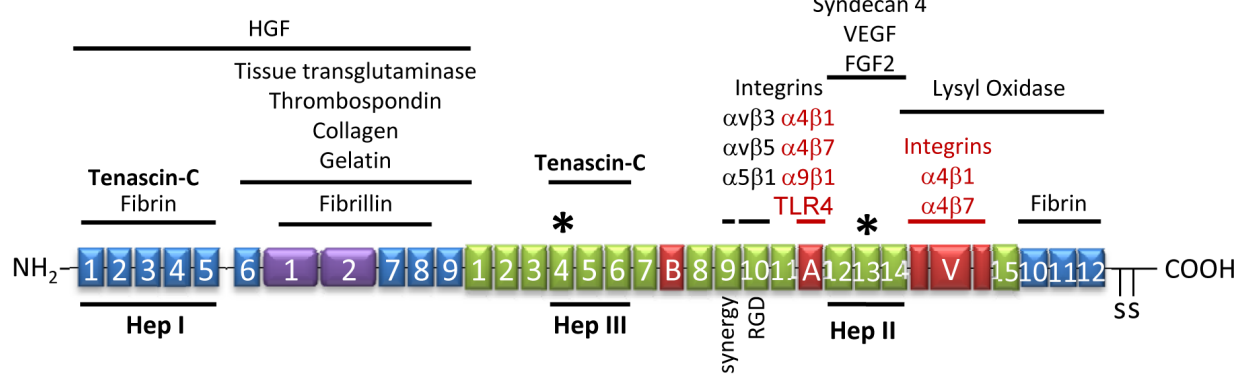

\section{B Tenascin-C}

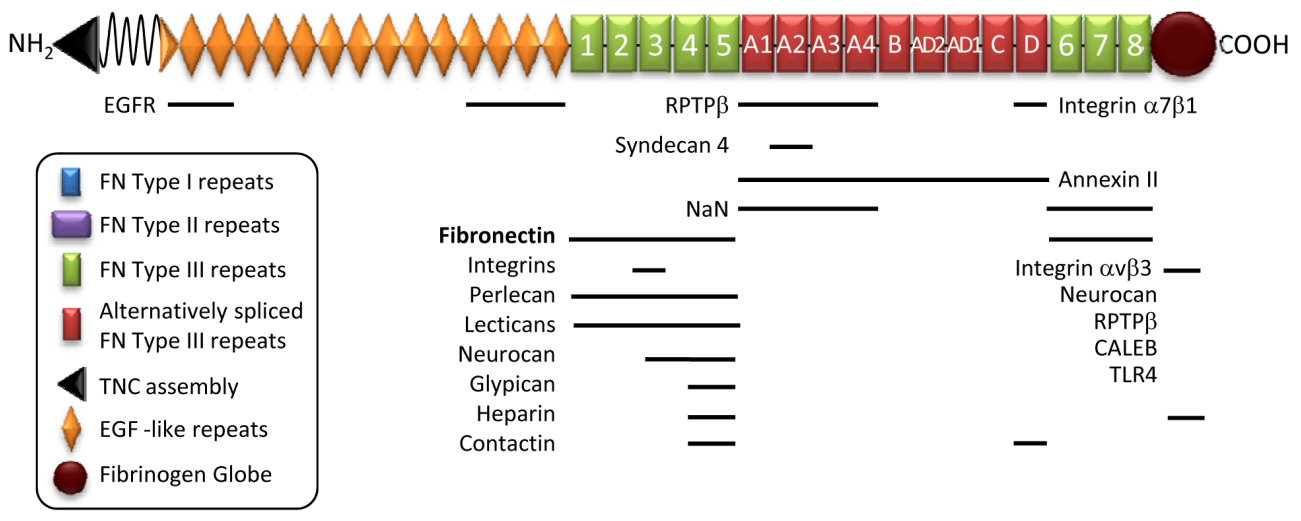


and references therein). Importantly for clinical applications, fibronectin splice variants containing the EDB and EDA domains, often referred to as oncofetal variants, are amongst the most specific markers of angiogenic blood vessels to date (Kaspar et al., 2006). In addition to promoting adhesion and signaling through cell surface receptors, the fibronectin matrix functions as a fibrillar scaffold for the assembly of other matrix proteins. Itprovides a platform for angiogenic signaling by increasing the bioavailability of soluble angiogenic factors, and cooperating with their transmembrane receptors (Hynes, 2007; Hynes, 2009; Miyamoto et al., 1996; Mosher et al., 1980).

Tenascin- $\mathrm{C}$ is another large modular ECM protein that exhibits a restricted and low expression in normal tissue. It is the founding member of the tenascin familiy with four members, tenascin- $C$, $-\mathrm{R},-\mathrm{W}$ and tenascin-X (reviewed in Chiquet-Ehrismann and Chiquet, 2003). All tenascins harbor several homologous domains that have been extensively described elsewhere (reviewed in Chiquet-Ehrismann and Chiquet, 2003; Orend, 2005; Orend and Chiquet-Ehrismann, 2006, Fig. 1). Tenascin-C can assemble into hexamers, it can be processed into monomers and it interacts with several cell surface receptors and other matrix molecules (reviewed in Midwood and Orend, 2009, Fig. 1). Its expression is elevated in embryonic tissues and in tissue of several cancers, and high tenascin- $C$ expression has been found to correlate with lymph node metastasis and poor prognosis (reviewed in Midwood and Orend, 2009). Tenascin- $C$ is one of the few genes within the signature of predictive value for lung metastatis in breast cancer patients (Minn et al., 2005). Moreover, a robust expression of tenascin- $C$ is associated with resistance to tamoxifen therapy in patients with estrogen receptor positive breast cancer (Helleman et al., 2008). Tenascin-C plays a yet poorly defined role
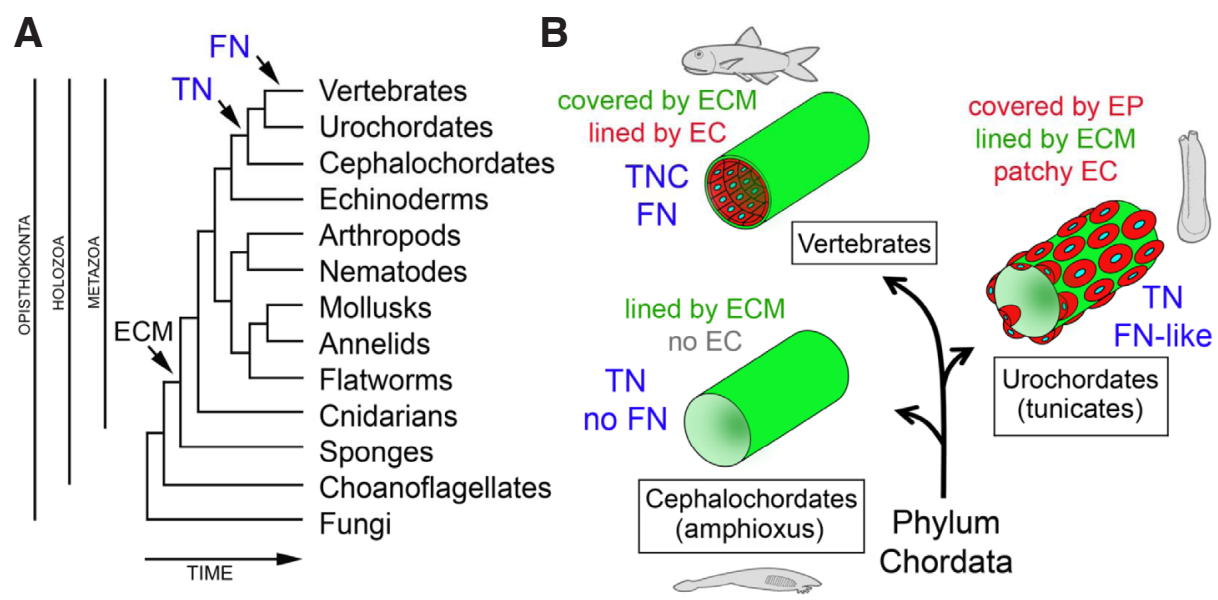

Fig. 2. Evolution of fibronectin and tenascin-C. (A) Integrins are found in single-celled holozoans and fungi, but extracellular matrix (ECM) first appeared in early metazoans. Tenascins (TN) and fibronectin (FN) evolved much later in basal chordates. (B) The evolution of blood vessels in the Phylum Chordata. In cephalochordates (also known as lancelets or amphioxus) the circulatory system is open, and blood vessels are matrix tubes without endothelial cells (EC) or surrounding epithelial cells (EP). Cephalochordates have a tenascin gene, but not a fibronectin gene. In urochordates (also known as tunicates or sea squirts) the circulatory system is also open. Blood vessels are lined by extracellular matrix and surrounded by epithelial cells. Occasionally cells are encountered lining the lumen of the vessels, but it is not known if these are endothelial cells. The urochordate Ciona has a tenascin gene and a fibronectin-like gene that lacks key features of vertebrate fibronectin. In vertebrates the circulatory system is closed and lined by endothelial cells; all vertebrates examined have multiple tenascin genes and a highly conserved fibronectin gene. in enhancing tumor cell proliferation, promoting angiogenesis, vasion and metastasis (Orend and Chiquet-Ehrismann, 2006) cellur responses relevant in angiogenesis, metastasis and the

At present, little is known about the interdependence of tenascin- $\mathrm{C}$ and fibronectin, yet a functional complicity of these two ECM molecules is strongly supported by their overlapping expression, physical interaction and modulatory role in cell esion-dependent processes (reviewed in Midwood and Orend, for is known about fibronectin and tenascin- $\mathrm{C}$ in angiogenesis, in pathologies including cancer.

\section{Evolutionary aspects of fibronectin and tenascin-C in}

The vasculature of vertebrates has a number of anatomical features that sets it apart from the vasculature of other members of the phylum Chordata. Notably, it is composed of a closed system of tubes lined by endothelial cells that are in turn invested by a asement membrane (Fig. 2). The urochordates (also known as closest relatives to the vertebrates (e.g., Putnam et al., 2008)), have what appear to be inside-out vessels, at least from a vertebrate's point of view: the lumen of the tunicate heart and major vessels is lined by the basement membrane of myoepithelial cells and not by an endothelium (Davidson, 2007). Cells are occasionally encountered lining the lumen of urochordate vasculature, and though these may represent endothelial-like cells, recent evidence suggests that in at least some colonial tunicates they are Piwi-positive stem cells (Rinkevich et al., 2010). In contrast to the closed system of vertebrates, the circulatory system of the tunicates is open, with the vessels leading from the heart emptying into lacunae where the hemolymph can bathe the organs. The cephalochordates (also known as lancelets or amphioxus), which are most likely a more distantly related invertebrate chordate, also have an open vascular system lined by ECM, but it lacks the epithelial lining of tunicate vessels (Fig. 2). For example, the aorta of amphioxus forms from the basement membranes of the gut endoderm and the ECM of the surrounding mesenchyme (Kucera et al., 2009). This primitive acellular matrix-tube vasculature is widely found in other invertebrates as well (Rupert 
and Carle, 1983; reviewed by Kucera and Lammert, 2009), even though invertebrates are perfectly capable of making tubular organs lined with epithelia like the trachea or salivary glands (e.g., see Castillejo-Lopez et al., 2004). Other anatomical features that are unique to the vertebrates include a lymphatic system and thymus (Bajoghli et al., 2009): no comparable systems are found in tunicates or amphioxus.

On the cellular, physiological and molecular levels the vertebrate circulatory system also has a number of unique features. For example, an adaptive immune system appears to have evolved with jawed fish (e.g., see Bajoghli et al., 2009), and amphioxus and tunicates lack the complex coagulation systems of vertebrates (Doolittle, 2009). Amphioxus and tunicates have many blood cells that appear to share roles with leukocytes, but they do not have erythrocytes (Cima et al., 2001; Huang et al., 2007). The tunicate Ciona has both globin and hemocyanin-related genes, but it is unknown if one or both play roles in respiration (Ebner et al., 2003).

Many ECM genes have origins that coincide with the appearance of basal metazoa, including collagens (Exposito et al., 2008), thrombospondins (Bentley and Adams, 2010) and syndecans (Chakravarti and Adams, 2006). Wnt and key players that make up the Wnt signaling pathways are present in sponges but not choanoflagellates, suggesting that they also evolved with the first metazoans (Richards and Degnan, 2009). Even more ancient are the integrins and molecules involved in integrin signaling like paxilin, talin and Integrin-linked Kinase (ILK) (Sebe-Pedros et al., 2010), some of which are in single-celled holozoans as well as fungi. In contrast, tenascins and fibronectin are encoded by relatively new genes, having evolved early in the chordate lineage. Of the two, tenascins appear to have evolved first, as the amphioxus Branchiostoma has a gene that encodes a tenascin that closely resembles vertebrate tenascins, but it lacks a fibronectin gene (Tucker and Chiquet-Ehrismann, 2009). Nothing is known about the expression of the amphioxus tenascin, but it is remarkable for having multiple (at least 7) copies of RGD motifs predicted to be exposed to integrin binding. It is interesting to speculate that at least some of the functions of fibronectin in vertebrates may be carried out in amphioxus by this RGD-rich form of tenascin. In contrast, the tunicate Ciona has a tenascin gene and a fibronectin-like gene, but the predicted protein encoded by the latter has distinctive features (e.g., it lacks an RGD motif and domains that correspond to EDA and EDB domains) that leads one to suggest that it may play different roles than its highly conserved vertebrate counterpart (Tucker and Chiquet-Ehrismann, 2009). Interestingly, the Ciona tenascin gene is expressed in the notochord and muscle cells, and is not associated with the developing heart (Kawashima et al., 2009; Tucker et al., 2006).

What can we learn from the evolution of ECM about the origins of the distinctive anatomical and molecular features of the circulatory system in vertebrates? Only in vertebrates do we see a closed circulatory system with proper endothelial cells, and during vertebrate development cells lining blood vessels, which are likely to be endothelial cells, express both tenascin (Tucker, 1993) and fibronectin (Astrof and Hynes, 2009; ffrench-Constant and Hynes, 1989). As we will see below, both tenascin- $C$ and fibronectin are critical for normal vascularization, so the appearance of these interrelated matrix molecules may have played a role in the evolution of this distinctive feature of vertebrates.

\section{Fibronectin and tenascin-C in loss of function models}

\section{Effect of a loss of fibronectin and its receptors on the vas- culature}

Genetic evidence points to a major role for fibronectin and its receptors in vascular development. Ablation of the fibronectin gene leads to embryonic lethality at embryonic day 9.5 (E9.5) with severe cardiovascular defects and aberrant somitogenesis (George et al., 1993). Interestingly, the severity of the defects was found to vary as a function of the genetic background of the fibronectinnull mice (George et al., 1997). A search for gene modifiers of the heart defects led to the identification of potential candidates on chromosome 4, proposed to affect a migratory process involved in coalescence of the two heart primordia into a single heart tube (Astrof et al., 2007b). The gene encoding tenascin- $\mathrm{C}$ is also located on chromosome 4, at a distinct locus. It is intriguing to speculate that tenascin- $C$ could participate in genetic interactions that determine the severity of the phenotype. Integrin $\alpha 5$-null mice lacking the main fibronectin receptor, $\alpha 5 \beta 1$, die at E10.5 with a phenotype similar to fibronectin-null mice (Francis et al., 2002; Yang et al., 1993). A comparable phenotype was observed in mice with an inactivating mutation of the $\alpha 5 \beta 1$-binding motif of fibronectin (RGD to RGE) (Takahashi et al., 2007), attesting to the functional importance of this ligand-receptor pair for vascular morphogenesis. Concerning the role of other fibronectin-binding integrins in vascular development and angiogenesis (reviewed in Hynes, 2007)), $\alpha v \beta 3$ and $\alpha v \beta 5$ integrins that bind to the RGD sequence in the cell-binding domain of fibronectin have received the most attention. Studies of integrin antagonists indicate that $\alpha \mathrm{V}$ integrins promote angiogenesis, while genetic deletion studies indicate that $\alpha v$ integrins are not required for angiogenesis. Although their exact function in angiogenesis has been subject to much debate (see (Astrof and Hynes, 2009; Desgrosellier and Cheresh, 2010; Hodivala-Dilke, 2008), $\alpha$ v-targeting agents are currently being developed or used in the clinic for cancer therapeutics.

Genetic ablation of the fibronectin gene deletes all fibronectin variants (up to 20 in humans). What about the role of the alternately spliced isoforms, and their cellular receptors? Selective ablation of EDB and EDA domains suggests that these domains confer essential functions to fibronectin, as evidenced by the early embryonic death of mice lacking both exons (Astrof et al., 2007a). However, the precise roles of these domains and the molecular events involved have yet to be fully understood, as compensatory mechanisms can rescue mice with single knock outs of either the EDB or EDA variant (recently reviewed in Astrof and Hynes, 2009; White et al., 2008). The EDB domain has been proposed to generate a conformational modification of fibronectin and improve the access to nearby integrin binding domains (see Balza et al., 2009; Bencharit etal., 2007; Carnemolla etal., 1992; Hashimoto-Uoshima et al., 1997; Ventura et al., 2010). This function is consistent with results from isoform-selective knockdown studies in endothelial cells (Cseh et al., 2010).

Whereas no EDB-specific cellular receptor has been identified to date, inclusion of the EDA repeat in c-fibronectin creates new binding sites for $\alpha 4 \beta 1$, $\alpha 4 \beta 7$ and $\alpha 9 \beta 1$ integrins (Kohan et al., 2010; Liao et al., 2002) (Fig. 1). $\alpha 4 \beta 1$ and $\alpha 9 \beta 1$ are structurally similar integrins that can bind to several ECM proteins; in the case of $\alpha 9 \beta 1$ this includes tenascin-C (Humphries et al., 2006; Yokosaki et al., 1998). Genetic and pharmacological studies in mice reveal a 
role for these integrins in the lymphatic vasculature. Hence, $\alpha 9 \beta 1$ null mice die between 8-12 days after birth from major defects in development of the lymphatic system (Huang et al., 2000). More recently, it was shown that the interaction between integrin $\alpha 9$ and fibronectin containing the EDA domain is required for fibronectin matrix assembly during lymphatic valve morphogenesis (Bazigou et al., 2009). Integrin $\alpha 4$ knock out mice die at E11.5 with cardiac malformations and placental defects. Interestingly, targeted deletion of $\alpha 4$ in lymphatic vessels or pharmacological inhibition of $\alpha 4 \beta 1$ was found to suppress growth factor- and tumor-induced lymphangiogenesis and prevent metastatic spread in vivo. In this same study, $\alpha 4 \beta 1$ and c-fibronectin were identified as markers of proliferative lymphatic endothelium in invasive tumors (GarmySusini et al., 2010). In addition to the EDA domain, sequences in the variable $(\mathrm{V})$ region (Fig. 1) can also bind to $\alpha 4 \beta 1$ integrin and thus contribute to the observed effects. Collectively, these findings shed light on the role of c-fibronectin variants as fundamental regulators of both blood and lymphatic vessels.

In humans, mutations in the fibronectin gene were identified in patients with glomerulopathy with fibronectin deposits (GFND), an autosomal dominant disease characterized by proteinuria, microscopic hematuria, hypertension, and massive glomerular deposits of non-fibrillar fibronectin in the mesangium and subendothelial space that lead to end-stage renal failure (Castelletti et al., 2008). These mutations affect the heparin binding domains Hep-II and Hep-III. Functional studies showed that mutant recombinant Hep-II fragments display lower binding to endothelial cells and podocytes, compared to wild-type Hep-II, and an impaired ability to induce endothelial cell spreading and cytoskeletal reorganization. Hep-II and -III domains participate in fibronectin assembly in ECM, through complex fibronectin-fibronectin and fibronectin-cell surface proteoglycan interactions (Singh et al., 2010). Interestingly, heparin-binding domains of fibronectin are sites of tenascin- $C$ binding and have been shown to mediate functional interactions between fibronectin and tenascin- $C$ that involve cell surface proteoglycans of the syndecan family, as discussed below.

\section{Effect of tenascin-C knock out on the vasculature}

Tenascin- $C$ knock out mouse was generated in two different laboratories (Forsberg et al., 1996; Saga et al., 1992). In both studies the signal peptide and the heptad repeat sequences were disrupted. Saga and colleagues inserted a lacZ-neo construct just in front of the translational initiation codon in exon 2 of the tenascin$\mathrm{C}$ gene, deleting parts of the exon 2 and intron 2 and keeping the regulatory unit of the tenascin- $\mathrm{C}$ gene for lac $Z$ expression (Saga et al., 1992). Since expression of a truncated tenascin- $C$ in these mice was detected (Mitrovic and Schachner, 1995), a second independent tenascin- $C$ knock out mouse was generated where a neomycin resistance cassette was inserted into exon 2 leading to two aberrant splice products of tenascin- $\mathrm{C}$ in homozygous mice inducing a frameshift and translation stop after 99 and 18 nucleotides (Forsberg et al., 1996). It is now clear that tenascin-C expression is lost in most tissues. Surprisingly, in both cases tenascin-C knock out mice were alive and fertile and exhibited an apparently normal development. The apparently normal development and tissue organization of these mice has been attributed to compensation mechanisms (reviewed in Orend and Chiquet-Ehrismann, 2006). It was noticed that in the subventricular zone of the brain oligodendrocyte precursor cells respond differently to growth factors and proliferate less, but this appears to be compensated by a reduced apoptosis rate later on. Thus the number of oligodendrocytes ends up being similar in the tenascin- $C$ knock out and wildtype mouse (Garcion et al., 2001). Later studies showed that the absence of tenascin- $C$ imposes problems for tissue homeostasis which is particularly evident during wound- or inflammation-associated tissue repair (reviewed in Orend and Chiquet-Ehrismann, 2006). Meanwhile tenascin- $C$ knock out mice present valuable tools for addressing the roles of tenascin- $\mathrm{C}$ in development, angiogenesis, inflammation, heart failure and tumorigenesis.

By using a cardiac allograft model it was shown that tenascin$\mathrm{C}$ is a mediator of postnatal cardiac angiogenic mechanisms in mice (Ballard et al., 2006). Upon subdermal transplantation of wild-type cardiac tissue into a syngenic host, a fibrin clot forms around the allograft and both the clot and cardiac tissue become vascularized, resulting in engraftment of viable cardiac tissue. Clot formation is unaffected in tenascin-C-null mice; however, these mice fail to form any vessels and no engraftment of cardiac tissue is observed. In wildtype mice the donor endothelial cells engrafted at sites of tenascin- $C$ expression, suggesting that tenascin- $C$ acts to promote homing and incorporation of endothelial or progenitor cells. Indeed, cultured rat cardiac microvascular endothelial cells adhere to tenascin- $C$ substrata, but spreading and monolayer formation are delayed compared to cells plated on fibronectin or collagen. Futhermore, migration of these cells into a collagen gel is enhanced when cultured on tenascin-C (Ballard et al., 2006). These data support a role for tenascin- $C$ in the early stages of angiogenesis by modulating endothelial cell adhesiveness, and thus promoting migration.

Tenascin-C also seems to play a role in vascularization associated with lung development. The tenascin- $C$ knock out mouse does not show apparent defects in lung anatomy and function, presumably due to unknown compensatory mechanisms. This compensation seems not to apply when the embryonic lung is placed in culture since the lung explants from tenascin- $C$ knock out embryos display reduced branching (defective cleft formation and enlarged terminal lung buds) and decreased vascularization (Roth-Kleiner et al., 2004). Results from another report indicate that lung vascularization and branching morphogenesis are dependent on Wnt and fibronectin signaling. Wnt signaling is turned on between E10.5 and E12.5 in the developing lung. Later (E13.5) Wnt signaling is largely reduced by Dickkopf (DKK) 1-3, and this coincides with induction of the Wnt target gene, fibronectin. Moreover DKK1 and fibronectin are instrumental in promoting lung branching morphogenesis and angiogensis, since recombinant DKK1 and anti-fibronectin antibody both block cleft formation and angiogenesis. DKK1 treatment causes thinner blood vessels, reduced sprouting from existing vessels and impaired formation of large vessels with fewer interconnections (De Langhe et al., 2005). Given that tenascin-C blocks fibronectin signaling, represses DKK1, and plays a role in lung branching morphogenesis, it is possible that a tight balance between fibronectin and tenascin- $C$ regulates normal lung branching and vascularization. In this scenario DKK1 repression by tenascin- $\mathrm{C}$ would result in Wnt activation and induction of fibronectin.

The role of tenascin- $\mathrm{C}$ in tumorigenesis was also investigated in a mouse model that develops metastasizing mammary gland tumors (due to ectopic expression of the polyoma virus middle Tantigen in the mammary epithelium) in the presence of wildtype 
tenascin- $\mathrm{C}$ or in a tenascin-C knock out setting (Talts et al., 1999). There was no difference observed in tumor onset, angiogenesis or metastasis between the genotypes, but the authors observed an altered organization of the tumor tissue. In tenascin-C wildtype tumors ECM molecules such as fibronectin, collagen I, nidogen and fibulin-2 were arranged in continuous long tracks whereas they were assembled in shorter matrix patches in the tenascin- $C$ knock out background. These structures might represent matrix channels that were subsequently identified by others in metastasizing melanomas (Kaariainen et al., 2006, see below). In contrast to melanomas, where the tenascin-C matrix channels seem to promote metastasis, other mechanisms might exist to promote metastasis in mammary gland tumors, in the absence of tenascin-C. It was also noted that tenascin- $C$ knock out breast carcinomas are significantly more infiltrated by activated macrophages (Talts et al., 1999). Since M2 macrophages promote tumor metastasis (Mantovani et al., 2008) it is possible that this species is increasingly attracted to the tissue that lacks tenascin-C. Previously it was shown that tenascin- $C$ inhibits $T$ lymphocyte adhesion to fibronectin (Hauzenberger et al., 1999) and activation (Puente Navazo et al., 2001). Thus, it is possible that in the tenascin-C knock out mammary gland carcinomas the inhibitory effect of tenascin- $\mathrm{C}$ is absent and this situation allows the attraction of macrophages. The reason why this would only affect a subset of macrophages needs to be addressed in the future.

In Balb/c-nude mice lacking tenascin-C, subcutaneously xenografted human melanoma cells made smaller tumors (Tanaka et al., 2004). In this model blood vessels were visualized by immunofluorescence upon injection of rhodamine-labeled gelatin, which allows selective visualization of perfused vessels that arise through sprouting angiogenesis. Despite a lack of quantitative data, the authors showed in tissue stainings that the arising tumor vasculature is reduced in the absence of host tenascin- $C$. They link this to reduced VEGFA expression in the tumor tissue. Although the melanoma cells exhibit strong tenascin- $C$ expression, this does not appear to have a significant impact on VEGFA levels in the tumor. These data suggest that tenascin- $C$ made by stromal cells has a major impact on VEGFA expression and that this mechanism potentially accounts for the angiogenesis promoting effect of tenascin-C (Tanaka et al., 2004).

\section{Effects of fibronectin and tenascin-C on the vasculature in tumors and in other pathological tissues}

Similar to fibronectin, tenascin- $C$ is only weakly expressed, or undetectable, in the ECM of quiescent vasculature. However, following vessel injury, tenascin- $C$ and fibronectin are highly upregulated. Tenascin- $C$ expression is strongly associated with sites of vascular remodeling during dermal tissue repair (Betz et al., 1993; Fassler et al., 1996; Latijnhouwers et al., 1996; Mackie et al., 1988). Tenascin-C expression is also highly associated with angiogenesis in a wide range of disease states, including diabetes, aortic aneurysm (Castellon et al., 2002; Jallo et al., 1997; Paik et al., 2004), artherosclerosis (Fischer, 2007), ulcerative colitis (Dueck et al., 1999), inflammatory bowel disease (Geboes et al., 2001), Crohn's disease (Riedl et al., 2001), vasculitis (Gindre et al., 1995) and cancer.

Recently, Berndt and collaborators reported the distribution of
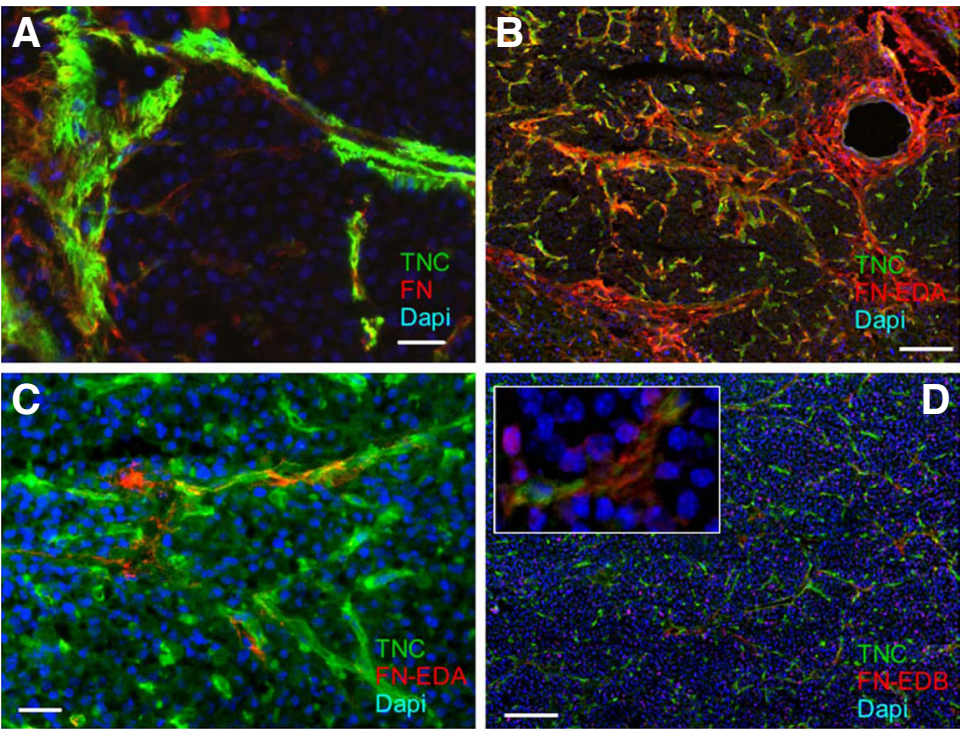

Fig. 3. Colocalization of fibronectin and tenascin-C in the tumor vasculature. (A-D) Tenascin-C and fibronectin expression in tumors. Coexpression of total fibronectin (A), FN-EDA (B,C) or FN-EDB (D) and tenascin-C in fibrils of an RT2 tumor (Gasser and Orend, unpublished). The anti FN-EDB antibody was kindly provided by Dr. A. K. Olsson (Uppsala University, Sweden). Scale bar 20 um $(A, C)$ and $100 \mu \mathrm{m}(B, D)$. Note the fibrillar organization of both molecules and their close apposition in tube-like structures, presumably representing blood vessels and/or matrix tubes.

tenascin- $C$ and fibronectin in several different carcinomas using antibodies specific for different splice variants (Berndt et al., 2010). Both proteins were generally present in the vessel wall, with fibronectin being preferentially localized at the luminal side and tenascin$\mathrm{C}$ at the extraluminal side of the vascular basement membrane. Interestingly, tumour vessels showed a heterogenous positivity for oncofetal fibronectin and tenascin- $C$ variants, with some vessels lacking both proteins, some vessels exclusively positive for fibronectin or tenascin- $C$, and other vessels surrounded by both matrix proteins. As an example, expression and partial colocalization of $\mathrm{c}$-fibronectin variants and tenascin- $\mathrm{C}$ in a murine $\mathrm{RT}$ 2 insulinoma is shown (Fig. 3). This stratified pattern clearly suggests a temporally and spatially regulated expression of these ECM proteins in the tumor vasculature and may reflect different maturation states of the vessels. In the study by Berndt et al., fibronectin was expressed by endothelial cells and carcinoma associated fibroblasts (CAFs) whereas tenascin- $\mathrm{C}$ was abundantly produced by carcinoma cells. It will be important to identify which cell types in various cancer tissues express tenascin- $\mathrm{C}$ and fibronectin with different domain structures. Further, it remains to be determined whether tenascin- $C$ and c-fibronectin variants with different domain compositions fulfill distinct roles in tumor angiogenesis.

Some light was shed on these questions by RNA expression analysis in breast cancer tissue. Amongst the more than 500 theoretically possible splice variants only 2 or 3 are usually expressed in cancer tissue, and these differ between cancers of different organs (reviewed in Orend, 2005). In invasive breast cancer, the authors found a prominent expression of a tenascin- $\mathrm{C}$ molecule with extra repeats $B$ and $D$ that is derived from the tumor cells, whereas a tenascin- $C$ molecule only expressing the $D$ domain appears to be expressed by carcinoma associated fibroblasts (reviewed in 
Guttery et al., 2010).

During tissue neovascularization, endothelial cells undergo pro-angiogenic activation, and assume a migratory morphology (Carmeliet, 2000; Ingber, 2002). Tenascin-C may promote tumor angiogenesis through several mechanisms, such as by serving as a chemoattractant for endothelial cells by initiating endothelial cell differentiation, or by promoting survival and proliferation. In vitro, tenascin-C is specifically upregulated by sprouting and cord forming bovine aortic endothelial cells but not by non-sprouting (i.e., resting) cells (Canfield and Schor, 1995; Schenk et al., 1999). This angiogenic phenotype is inhibited when cells are grown in the presence of anti-tenascin-C antibodies, suggesting that the transition from a resting to a sprouting phenotype may be promoted by tenascin-C (Canfield and Schor, 1995). Indeed, soluble tenascin-C reduces focal adhesions in endothelial cells (Chung et al., 1996; Murphy-Ullrich et al., 1991) and enhances endothelial cell migration (Chung et al., 1996). These events appear to involve integrin $\alpha v \beta 3$, FAK and Prx1 amongst other, not yet identified, molecules (reviewed in Orend and Chiquet-Ehrismann, 2006).

\section{Counter-adhesive activities of fibronectin and tenascin-C}

Shortly after its discovery in the early 1980s as myotendinous antigen (Chiquet and Fambrough, 1984), as glioma-mesenchymal extracellular matrix molecule (GMEM) (Bourdon et al., 1983) and as neuronal protein janusin J1 (Faissner et al., 1988) it was noted that tenascin-C can bind to fibronectin (Chung et al., 1995; Lightner and Erickson, 1990). Since then, several reports have extended this finding although some controversy exists whether the long and/or the short form of tenascin-C (i.e. including or lacking the alternatively spliced fibronectin type III repeats, respectively) (Chiquet-Ehrismann et al., 1991; Chung et al., 1995; Huang et al., 2001) have different affinities for fibronectin. All three heparin binding domains seem to bind tenascin-C, with Hep-I being cryptic and exhibiting low affinity (Ingham et al., 2004). Tenascin-C binds to the Hep-III domain in fibronectin, but it is not known whether this interaction competes with binding of cell adhesion receptors. Binding of tenascin-C to the fibronectin-Hep-II domain blocks cell spreading (Chiquet-Ehrismann et al., 1991; Huang et al., 2001; Midwood et al., 2004a; Orend et al., 2003) and fibronectin fibrillogenesis (To and Midwood, 2010) through competition with syndecan-4. The Hep-II domain serves as coreceptor for the major fibronectin binding integrin $\alpha 5 \beta 1$ (Fig. $4 \mathrm{~A}, \mathrm{~B}$ ). The exact binding site in fibronectin has been mapped to the $13^{\text {th }}$ fibronectin type III repeat within the Hep-II domain, and a peptide representing 10 amino acids of the cationic craddle rescued tenascin- $\mathrm{C}$ induced cell rounding (Huang et al., 2001; Orend et al., 2003). Activation of syndecan-4 signaling induced upon ectopic expression of syn-

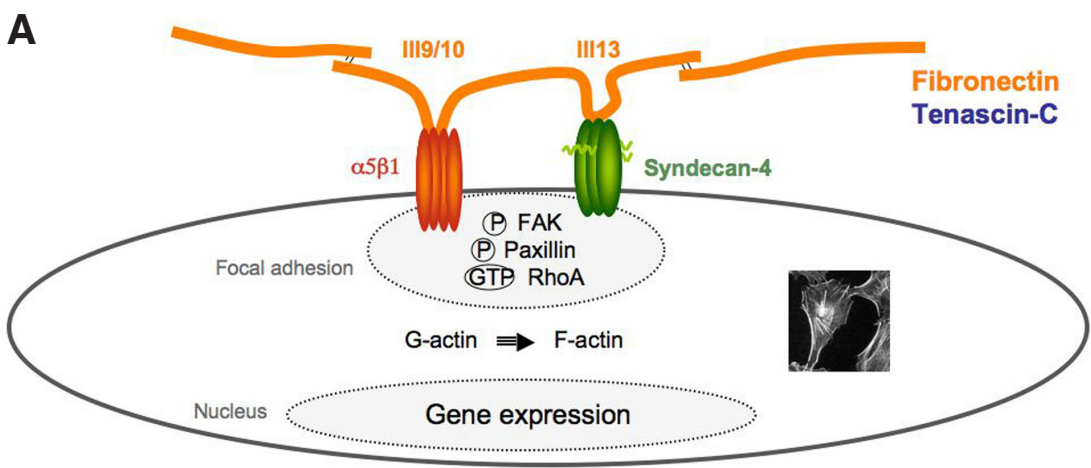

B

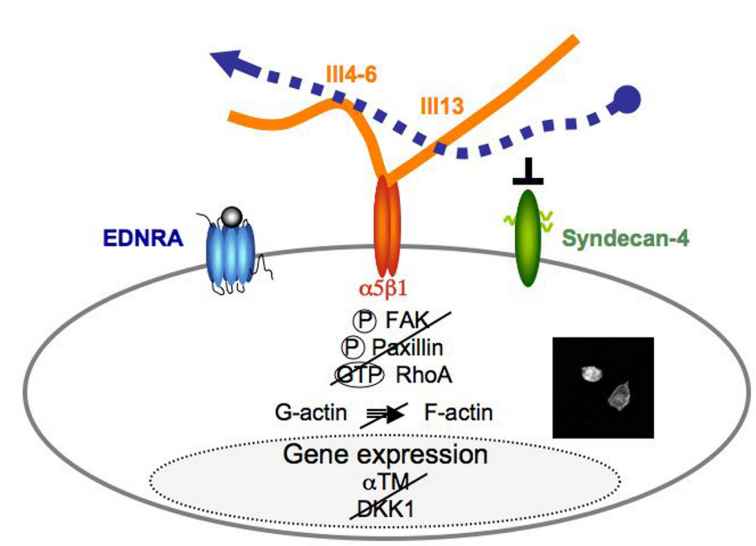

C

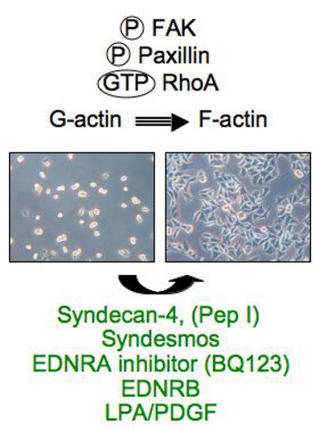

Fig. 4. Inhibition of syndecan-4 by tenascin-C. (A) Cells activate integrin $\alpha 5 \beta 1$ and syndecan- 4 upon adhesion to their respective binding sites in fibronectin (FN type III repeats 9 and 10, and 13, respectively). This induces formation of focal adhesions. Crucial steps in cell spreading are phorphorylation of focal adhesion kinase (FAK) and paxillin and GTP loading of RhoA. Consequently, G-actin is polymerized into F-actin and cells spread on fibronectin. (B) Tenascin-C binds to the 13th FN type III repeat in fibronectin thus competing for cell binding to this domain. This mechanism applies to tumor cells and fibroblasts, but has yet to be addressed in endothelial cells. In the presence of tenascin-C, FAK and paxillin stay unphosphorylated and $R$ hoA remains inactive (Huang et al., 2001, Midwood and Schwarzbauer, 2002). No focal adhesions or actin stress fibers are formed. The rounded cell shape translates into altered gene expression and causes repression of alpha tropomyosin ( $\alpha$ TM) and Dickkopf-1 (DKK1) as well as induction of endothelin receptor type $A$ (EDNRA) amongst changes in expression of several other genes (Ruiz et al., 2004). (C) The rounded cell shape can be reverted on a fibronectin/tenascin- $C$ substratum upon activation of syndecan-4 with a peptide (pep I) that mimics the cationic craddle in syndecan-4 or upon overexpression of syndesmos, a molecule that binds to the cytoplasmic tail of syndecan-4 and provides a molecular bridge in the focal adhesions to proteins binding to integrins (Baciu et al., 2000; Lange et al., 2008; Orend et al., 2003). Inhibition of EDNRA with BQ123 also induces cell spreading (Lange et al., 2007). Combined signaling from platelet derived growth factor (PDGF) and the lysophosphatidic acid (LPA) and by endothelin receptor type B (EDNRB) involving the EGFR induce cell spreading on the mixed fibronectin/tenascin-C substratum. Signaling by these molecules induces focal adhesion and actin stress fiber formation although with a cell shape that is particular for each treatment. Nevertheless, repression of $\alpha$ TM is ablated and tropomyosins 1-3 are expressed to stabilize actin stress fibers (Lange et al., 2007; Lange et al., 2008). Regulation of $\alpha$ TM is crucial for cell spreading on fibronectin since its knock down inhibits cell spreading on fibronectin and interferes with restored cell spreading on the fibronectin/tenascin-C substratum upon treatment with pep I and activation of LPA receptors and PDGF receptors or EDNRB (Lange et al., 2007; Lange et al., 2008). 
decan-4 (but not of syndecan-1 or -2) rescued tenascin-C-inhibited cell spreading on fibronectin (Huang et al., 2001; Midwood et al., 2004b; Orend et al., 2003) as did overexpression of syndesmos, a molecule that binds to the cytoplasmic tail of syndecan- 4 and triggers downstream signaling (Lange et al., 2008, Fig. 4C). The major binding site for fibronectin-Hep-II may reside in the 6-8 fibronectin type III repeats of tenascin-C as was deduced from antibody blocking experiments (Chiquet-Ehrismann et al., 1988; Riou et al., 1990). This is now supported by a recent report demonstrating that memprin $\beta$-cleaved tenascin- $C$ loses its anti-adhesive properties in a fibronectin context (Ambort et al., 2010). The authors showed that memprin $\beta$ cleaves within the $7^{\text {th }}$ fibronectin type III repeat of tenascin- $C$ thus destroying this interaction site, and that memprin $\beta$-cleaved tenascin-C does not interfere with cell spreading on fibronectin (Ambort et al., 2010). Inhibition of syndecan-4 by tenascin- $C$ prevents focal adhesion formation, blocks activation of FAK and paxillin and has a strong negative impact on expression and protein stability of RhoA and tropomyosin 1-3 (Lange et al., 2007; Lange et al., 2008), and Rho activation (Midwood et al., 2006). The effect on the cytoskeleton appears to be instrumental in cell rounding by tenascin-C since ectopic expression of tropomyosin-1, an actin stress fiber stabilizing molecule with tumor suppressor activity, restores cell spreading which is linked to FAK and paxillin phosphorylation (Lange et al., 2007).

Binding of tenascin-C to the Hep-Il domain of fibronectin can also have implications for angiogenic growth factor signaling. Indeed, it has been shown using molecular and biochemical approaches that several growth factors (up to 25, including VEGF, HGF, FGF-2, PDGF-BB and TGF- $\beta 1$ ) bind to this domain (see (Hynes, 2009; Martino and Hubbell, 2010). Moreover, fibronectin-Hep-II-bound growth factors are even more potent than their un-bound counterparts in triggering capillary morphogenesis of endothelial cells in fibrin gels (Martino and Hubbell, 2010). Although not shown in endothelial cells, cellular responses to tenascin- $C$ can be modulated by growth factors. Thus, in fibroblasts and tumor cells growth factor signaling can override the necessity of syndecan- 4 in fibronectin-induced cell spreading. Combined signaling from LPA and PDGF-BB (but not from each factor alone) restores cell spreading on a fibronectin/ tenascin- $C$ substratum even in cells that lack syndecan-4 (knock out) in a PI3K- and MEK-dependent manner, and this is linked to restored high expression of tropomyosins 1-3 and RhoA (Lange et al., 2008, Fig. 4C). Again, high levels of tropomyosin 1-3 are essential since sh-mediated knock down of the tropomyosins 1, 2 and 3 counteracts LPA/PDGF-BB-induced cell spreading on the fibronectin/tenascin-C substratum (Lange et al., 2008).

Adhesion to a fibronectin/tenascin-C substratum also has long term consequences as revealed by RNA profiling (Ruiz et al., 2004). In particular, $12 \mathrm{~h}$ after plating, endothelin receptor type A (EDNRA) is induced 5-fold, and, signaling through this receptor maintains cell rounding by tenascin-C since it is blocked by a specific EDNRA inhibitor. EDNRA associated cell rounding occurs in a MEKdependent manner and EDNRA inhibition causes cell spreading with activation of FAK and restoration of tropomyosin and RhoA levels (Fig. 4 B,C). These studies also reveal that, depending on the receptors present on the membrane, interactions with tenascin$\mathrm{C}$ can be interpreted very differently. In particular, in contrast to EDNRA signaling that induces tenascin- $C$ cell rounding, activation of EDNRB restores cell spreading through a different pathway that does not involve MEK but does involve EGFR, PLC $\gamma$, PI3K and
JNK (Lange et al., 2007, Fig. 4C). Thus, whether cells respond to a fibronectin/tenascin- $\mathrm{C}$ matrix by rounding or spreading appears to be highly regulated and may have an impact on cell function, tissue stiffness and vessel diameter. Both endothelin receptors play an important role in modulating blood pressure and are linked to high blood pressure in heart disease and artherosclerosis (Nguyen et al., 2010). Since tenascin- $C$ is expressed in diseased heart tissue and artherosclerosis, it remains to be determined whether tenascin-C-associated EDNRA signaling plays a role in blood pressure regulation that has an impact in heart diseases.

Tenascin-C potentially plays a role in EDNRA-associated events involving angiogenesis, e.g., in ovarian cancer progression. Primary and metastatic ovarian cancer cells not only overexpress tenascin-C (Wilson et al., 1999; Wilson et al., 1996) but also EDNRA and its ligand endothelin-1 (ET1) (Rosano et al., 2001). EDNRA signaling contributes to tumor angiogenesis presumably through stabilization of HIF- $1 \alpha$, induction of VEGFA (Grimshaw, 2007) and $\beta$-arrestinlinked Wnt signaling (Rosano et al., 2001).

A tenascin- $C$ - EDNRA axis might also be relevant in tumor cell migration and tumor lymphangiogenesis (Cueni et al., 2010). Tumors derived from xenografted breast adenocarcinoma cells that ectopically express the orphan receptor podoplanin induce lymphatic vessels, whereas this was not observed in tumors of control cells with low or no podoplanin expression. RNA profiling of microdissected areas of the invading tumor front revealed overexpression of tenascin-C, ET1 and the ERM member villin. Previously it was shown that binding of the ERM family member ezrin to the cytoplasmic tail of podoplanin induces filopodia which was linked to collective tumor cell migration (Wicki et al., 2006). These results suggest that ET1 signaling may induce migration on a tenascin- $C$ substratum by podoplanin through its link to the actin cytoskeleton.

In addition to EDNRA, Wnt signaling is also induced in glioblastoma cells on a fibronectin/tenascin-C substratum. In particular, DKK1 is repressed, $\beta$-catenin stabilized and Wnt targets such as Id2 are induced (Ruiz et al., 2004). This observation could be relevant in glioblastomas where a high expression of Id2 and tenascin-C correlated with malignancy (Ruiz et al., 2004). Given that Wnt signaling is instrumental in angiogenesis, by triggering endothelial cell proliferation and sprouting (reviewed in Franco et al., 2009), it remains to be determined whether tenascin-C promotes angiogenesis through Wnt signaling. Since EDNRA and Wnt signaling are linked through $\beta$-arrestin (Rosano et al., 2009) and through ET1-induced DKK1 repression (Clines et al., 2007) it is possible that tenascin- $C$ enhances this cross-talk by activating both pathways.

\section{Organization of fibronectin and tenascin-C into matrices}

\section{Fibronectin assembly and angiogenesis}

Fibrillar organization is a key feature of the ECM. Many of the functions of fibronectin depend not only on its linear sequence but on the 3-dimensional structure of the protein and its assembly into a functional fibrillar matrix (see Mao and Schwarzbauer, 2005). Due to its compact conformation, fibronectin does not form fibrils in solution. Rather, fibril assembly is a cell-driven process in which $\alpha 5 \beta 1$ integrin plays a major role (recently reviewed in Singh et al., 2010) and shown diagrammatically in Fig. 5). Importantly, soluble fibronectin selectively binds to $\alpha 5 \beta 1$ integrin, and not other RGD-binding 
integrins (Huveneers et al., 2008). Hence, bloodborne p-fibronectin in quiescent vessels is segregated from $\alpha 5 \beta 1$ integrins, located on the abluminal surface of endothelial cells. Studies to elucidate the mechanisms of fibronectin fibrillogenesis in endothelial cells have revealed a determinant role for ILK in this process (Vouret-Craviari et al., 2004). ILK, an integrin beta subunit adaptor, regulates actin dynamics and fibronectin fibrillogenesis by recruiting actin-binding regulatory proteins such as $\alpha$-parvins and tensin (Legate et al., 2006; Stanchi et al., 2009) involved in generating acto-myosin contractility for fibril growth. More recently, loss of function studies have revealed that fibronectin fibrillogenesis in endothelial cells is a cell autonomous process, wherein basally directed secretion of autocrine fibronectin is tightly coupled to fibronectin assembly and cadherin-based junction formation (Cseh et al., 2010). These results highlight the importance of spatial and temporal regulation of c-fibronectin expression and they support a model in which the induction of cellular c-fibronectin expression by angiogenic factors triggers the deposition of a perivascular fibrillar matrix.

One example of how transient c-fibronectin expression participates in a "pro-angiogenic switch" comes from elegant studies on vascular patterning in the developing retinal vasculature (Gerhardt

A

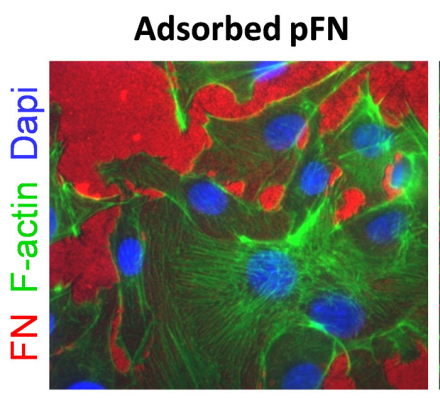

C

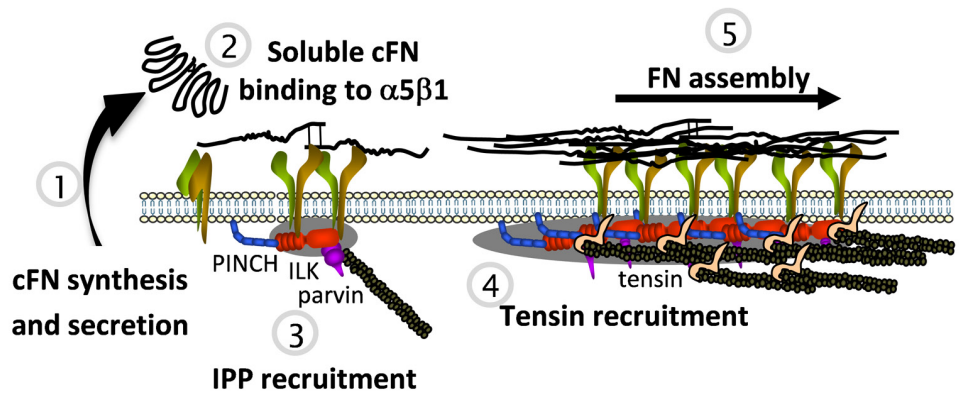

Fig. 5. Fibrillar organization of c-fibronection in endothelial cells and mechanisms of assembly. $(\mathbf{A}, \mathbf{B})$ Immunostaining of fibronectin in bovine aortic endothelial cells plated on adsorbed p-fibronectin (left) or non-coated (right) coverslips. Upon adsorption, fibronectin undergoes conformational changes (stretch-induced "activation") that modify its interaction with other proteins (e.g. cellular receptors, ECM components) and affect its biological activity. Note the increase in stress fiber formation in cells plated

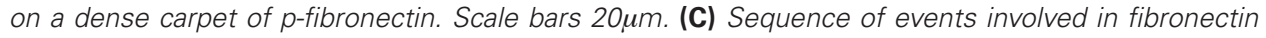
assembly. Work from numerous laboratories have contributed to the understanding of fibrillogenesis that can be summarized as follows (for a detailed review see Singh et al., 2010. Binding of secreted $c$-fibronectin to inactive $\alpha 5 \beta 1$ integrins (bent conformation) leads to integrin activation, clustering, and recruitment of integrin effectors, such as ILK, PINCH, parvin (IPP complex, (Legate et al., 2006)) and tensin that mediate cytoskeletal linkage and actin crosslinking. Acto-myosin-generated contractility "streches" the integrin-bound fibronectin, thereby exposing cryptic self-assembly sites and fibrillogenesis proceeds as integrins translocate along paths of growing fibrils. et al., 2003; Jiang et al., 1994; Uemura et al., 2006). During this process, blood vessels use the existing astrocyte network as a vessels, fibronectin expression becomes dramatically down in the astrocytes and turned on in the endothelial cells the expression and localization of tenascin- $C$ in this model.

Once assembled, fibronectin fibrils provide a scaffold for the assembly of a growing list of matrix proteins, including fibrillar ens, thrombospondin-1, fibulin-1, fibrinogen, fibrillins and cross-linking enzymes such as tissue transgluProtein-1) and substrates (e.g., procollagen, biglycan and chordin, Huang et al., 2009).

Fibronectin and tenascin-C co-assemble into a matrix

Apart from the $\alpha 5 \beta 1$ integrin, other fibronectin-binding integrins have been reported to promote fibrillar assembly, albeit less efficiently (see Leiss et al., 2008). Fibronectin matrix is also regulated by molecules that affect integrin expression or function, including transmembrane molecules (e.g., syndecans 2 and 4, the receptor for urokinase-type plasminogen activator, CD98hc, VEGFR1 and neuropillin), intracellular proteins (e.g., the tumor suppressor von Hippel-Lindau protein) or extracellular components (e.g., extracellular Alix ALG-2-interacting protein X). With regard to functional interactions between fibronectin and tenascin- $C$ that impact matrix formation, they are likely to involve effects on the fibronectin matrix mediated by syndecans 2 and 4, and regulation of intracellular signaling events that accompany fibronectin binding to integrins, as mentioned above. Proteoglycans, such as decorin and periostin, known to modulate fibronectin matrix assembly (Kii et al., 2010; Kinsella et al., 2000) are essential for matrix incorporation of tenascin-C (Chung and Erickson, 1997; Kii et al., 2010). It is known that tenascin-C can bind to purified fibronectin and co-localize with fibronectin fibrils on the surface of cultured cells (e.g., Ramos et al., 1998). A recent study in fibroblasts involving the use of recombinant tenascin- $C$ domains demonstrated an inhibitory effect of tenascin-C domain III 1-8 (fibronectin type III domains 1-8) on the formation of an insoluble fibronectin matrix, whereas the full length protein was without effect (To and Midwood, 2010). These data 
suggest that conformational changes may expose fibronectintenascin-C interaction sites that are important for regulation of matrix assembly in vivo.

\section{Tenascin- $C$ and fibronectin in tumor matrix tubes}

In breast cancer tissue tenascin- $C$ causes remodeling of the matrix. This effect, apparent at first glance by disruption of the basement membrane, can be seen in tumors and in cultured mammary epithelial cells. Using a 3-dimensional model of breast tumor cells, Taraseviciute and colleagues showed that tenascin- $C$ interferes with basement membrane assembly in a c-Met dependent manner. In presence of tenascin- $C$ the mammary epithelial cells proliferate and fill the acini lumen (Taraseviciute, 2009). In cancer tissue, the expression of tenascin- $\mathrm{C}$ is frequently not homogenous. Rather, it accumulates in matrix tracks as seen in the tissue of malignant melanomas (Kaariainen et al., 2006), breast (Degen et al., 2007) and colorectal carcinomas (Degen et al., 2008). In the case of melanomas, the combined high expression of tenascin- $C$ and fibronectin, amongst other factors, was found to discriminate between metastatic and non-metastatic malignancies. The switch to an invasive phenotype was associated with the presence of tenascin-C and fibronectin, colocalized with laminin and procollagen in tubular channels containing tumor cells, but not blood endothelial or lymph endothelial cells (Kaariainen et al., 2006). In another study gene profiling revealed a panel of ECM molecules, including tenascin- $C$, several laminins, and collagens that were highly expressed in metastatic breast cancers from MMTV-VEGF/c-myc transgenic mice, whereas their expression was largely reduced or undetectable in non-metastaticc-myc-induced tumors (Calvo et al., 2008). These studies suggest that a combined high expression of distinct ECM molecules, including tenascin- $\mathrm{C}$ and fibronectin, and their assembly in matrix channels, is somehow linked to metastasis.

The existence of vessel-like structures that are distinct from blood and lymphatic vessels has been known for a long time and was described as vasculogenic mimicry (VM) (Hendrix et al., 2003). VM is characterized by the large absence of endothelial cells and by staining with PAS (Periodic Acid Schiff reagent), which identifies proteoglycans with glycosaminoglycan residues present in the ECM without further information on the molecular nature of these proteoglycans. It is likely that the matrix tubes that contain tenascin- $\mathrm{C}$ and fibronectin described in melanomas (Kaariainen et al., 2006) are part of the PAS-positive structures that are characteristic of VM. In a large number of different cancers including melanoma, uveal melanomas, colorectal carcinoma, ovarian carcinoma (summarized in Kucera and Lammert, 2009) and astrocytoma (El Hallani et al., 2010), VM is frequently associated with metastasis and bad prognosis. It is claimed that several forms of VM exist, which are classified according to the degree and nature of cells that associate with the ECM: no endothelial cells, patchy distribution of endothelial cells, tumor cells only, or a combination of both cell types. By comparing in vitro cultures of cancer cells that do or do not exhibit VM in vivo, several VM-associated molecules have been identified. These include $\gamma 2$ chain containing laminins, several metalloproteases (MMPs 1, 2, 9 and 14), Cox2, PI3K, EphA2, nodal and pigment epithelial derived factor, amongst a list of growing candidates (reviewed in Dome et al., 2007; Paulis et al., 2010). Eventually, cells are found associated with matrix structures: melanoma cells, and erythrocytes in tenascin- $C$ matrix channels (Kaariainen et al., 2006), and macrophages along collagen-rich tracks found in so called co-opted vessels (Pollard, 2008). Although matrix structures had been identified that appear to be different, more work is needed to clarify whether they are potentially part of the same matrix network.

Currently there is little known about the functional significance of these matrix structures in respect to tumor angiogenesis and progression. However, there is experimental evidence that cancer cells can use the tenascin-C-containing matrix tubes to disseminate. In a coculture experiment of fibroblasts together with squamous carcinoma cells, the fibroblasts scouted their way through collagenenriched matrigel by degrading the ECM at the front. Tubes were left behind that were filled with fibronectin and tenascin- $\mathrm{C}$. The squamous carcinoma cells invaded the matrigel by using these matrix tubes (Gaggioli et al., 2007). It was previously shown that carcinoma-associated fibroblasts or TGF $\beta 1$ treated fibroblasts (differentiating into myofibroblasts) secrete tenascin- $C$ into the collagen gels preparing a path for colorectal carcinoma cells to invade in a c-MET- and EGFR-dependent manner, involving activation of Rac and inhibition of RhoA (De Wever et al., 2004). They proved a crucial role of tenascin- $C$ in these events since invasion was inhibited with an anti-tenascin- $C$ antibody. Whether fibronectin plays a role in these structures is unknown, but likely.

Evolutionary development of endothelium-lined blood vessels in vertebrates seems to have followed laminin-based matrix tracks in invertebrates (Kucera et al., 2009) (Fig. 2). In amphioxus, lamininfilled tubes are laid down as a scaffold in which a hole is drilled by cells of unknown origin to generate a coelom that allows blood to circulate (Kucera et al., 2009). As mentioned above the tenascin-C gene is present in amphioxus and it remains to be seen whether tenascin- $C$ is part of this matrix circulation network. In co-cultures of endothelial cells with a macrophage cell line, where the endothelial cells deposit laminin, macrophages create a coelom-like cavity by partially digesting and clearing the ECM to generate space. Thus, it is possible that this ancient vessel program is turned on in tumors to establish the observed matrix-based networks. More information about the composition of the matrix blood vessels in chordata and in human cancers is necessary to elucidate this possibility further. The observed tenascin- $\mathrm{C}$ matrix tubes in melanomas and other cancers may offer a route for dissemination of tumor and other cells through their continuum with blood vessels. They also potentially provide a scaffold to support growth of blood vessels. This possibility is interesting, considering that anti-angiogenic therapeutic approaches, despite efficient killing of the endothelial cells, fail in the long-run, and even promote tumor progression and earlier tumor metastasis (Paez-Ribes et al., 2009; Stockmann et al., 2008). Tenascin-C matrix tubes would not be affected by antiangiogenic drugs. Indeed, Fusenig and coworkers (Vosseler et al., 2005) demonstrated that expression of tenascin- $C$ in xenografts of squamous carcinoma cells is unchanged upon elimination of the endothelial cells with a VEGFA-targeting antibody.

Matrix tubes containing tenascin- $\mathrm{C}$ are also present in a normal setting in mammals in so called reticular fibers of secondary lymphoid tissues such as lymph nodes, thymus and spleen (Lokmic et al., 2008). They combine characteristics of basement membranes and fibrillar matrices, resulting in scaffolds that are strong and flexible, and in certain organs, such as the spleen and the thymus, form conduit networks for rapid fluid transport and cells (Lokmic et al., 2008). In the thymus, the conduits exhibit a collagen core, a laminin wrapping and an outer lining of tenascin-C (Drumea-Mirancea et 
al., 2006). Fibronectin is also part of the reticular fiber network (Sobocinski etal., 2010). Whether tenascin-C and or fibronectin are required for the formation and function of the conduits is not known.

We speculate that a program may exist for the establishment of structured matrix that is potentially turned on inappropriately in cancer resulting in the described tenascin-C/fibronectin-containing matrix tubes. It is also tempting to consider that tubular matrix structures containing fibronectin and tenascin-C had developed once during evolution and were potentially further developed to fulfill other needs such as a transport system for maturing macrophages in reticular fibers, as scaffold for endothelial cell lined vessels and as an instructive matrix for branching morphogenesis. It will be important to understand how these matrix networks are created, and which signals induce their emergence.

Lysyl oxidase, transglutaminase and other enzymes modifying fibronectin may be relevant in modulating interactions of fibronectin with tenascin- $\mathrm{C}$ and other matrix molecules. It is likely that monomeric rather than bulky hexameric tenascin- $C$ is part of a dense tubular matrix network. Monomeric tenascin- $\mathrm{C}$ can be generated upon cleavage by several proteases that are abundant and active in cancer tissue. In particular, separation of the $\mathrm{N}$-terminal part from the remainder of the molecule seems to result in the release of monomeric tenascin-C from the hexamer (Mackie, 1997). The $\mathrm{N}$-terminal oligomerizing part of tenascin-C can be cleaved off by memprin $\alpha$ and $\beta$ (Ambort et al., 2010), pepsin (Chiquet et al., 1991), trypsin (Fischer et al., 1995) and MMP7 (Siri et al., 1995).

It will be necessary to determine what exact role tenascin-C plays in the matrix tubes in cancer. Recently, it was found that cancers are able to trick the immune system by using a chemokine signaling program that would mischievously tell the body that the tumor is a lymphoid tissue (Shields et al., 2010) and thus trigger tumor evasion. Given that lymphocytes use the reticular fiber system to translocate within the lymphoid tissue and that tenascin-C and fibronectin are structural components of the reticular fibers it will be interesting to see whether these matrix molecules play a role in immune evasion in reticular fibers and in cancer. Assuming that ancient programs developed in evolution and are potentially involved in the creation of tubular matrix structures in mammals, it is intriguing to speculate that laminins and integrins may play an initial role followed by tenascin-C, fibronectin and other ECM molecules that were developed later during evolution.

\section{Potential applications and outlook}

Together, these data demonstrate that tenascin- $\mathrm{C}$ and fibronectin are key players in tumor angiogenesis and metastasis, and they represent attractive anti-cancer targets. Drugs targeting tenascin-C and c-fibronectin, or interactions with their cellular receptors are currently being developed, or have already reached clinical trials (reviewed in Desgrosellier and Cheresh, 2010; Midwood and Orend, 2009; Pedretti et al., 2009; Schliemann and Neri, 2010). Novel approaches involving immunization against the EDB domain of c-fibronectin also may provide interesting alternative strategies for interfering with tumor angiogenesis and cancer growth (Huijbers et al., 2010). To optimize potential treatments, several questions related to the biology of these relatively new (evolutionarily speaking) ECM proteins remain to be further addressed. Many secrets appear to be hidden in their topographical organization, some of which may be revealed by comparing cancer tissue with embryonic tissue, and the
ECM of different types of cancer. Beyond circumstantial evidence, do these molecules collaborate or counteract each other in induction of pro-angiogenic signaling and blood vessel remodeling? Does this occur through a receptor-mediated mechanism or indirectly e.g. by modulating signaling of proangiogenic growth factors? What are the mechano-regulatory mechanisms involved? How is their spatial regulation (different cells) and temporal regulation in tumors controlled? Do both molecules serve as chemoattractants for endothelial cells or their precursors? How are they involved in the recruitment of mural cells or cells of the hematopoetic system? Finally, do fibronectin and tenascin-C-containing matrix channels support regrowth of vessels in residual tumor tissue upon an anti-angiogenic therapy? Finding answers to these questions will require the complicity of many researchers. The answers should clarify the function of ECM in the evolution and development of vasculature, and should lead to the discovery of more effective therapies for fighting tumor growth and metastasis.

\section{Acknowledgements}

We apologize to all authors whose work we did not have space to mention. The laboratories of EVOS and GO are financially supported by INSERM, the Agence National de la Recherche, the Association pour la Recherche sur le Cancer and the Institut National du Cancer. EVOS was additionally supported by the University of Nice-Sophia Antipolis, CNRS and the Centre A. Lacassagne; and GO by Oncosuisse, the University Hospital Hautepierre and the University Strasbourg. I.G. was supported by Inserm Region Alsace. Anti-FN-EDB antibody was generously provided by A.K. Olsson, Uppsala University, Sweden.

\section{References}

AMBORT, D., BRELLIER, F., BECKER-PAULY, C., STOCKER, W., ANDREJEVICBLANT, S., CHIQUET, M. and STERCHI, E.E. (2010). Specific processing of tenascin- $C$ by the metalloprotease meprinbeta neutralizes its inhibition of cell spreading. Matrix Biol 29: 31-42.

ASTROF, S., CROWLEY, D. and HYNES, R.O. (2007a). Multiple cardiovascular defects caused by the absence of alternatively spliced segments of fibronectin. Dev Biol 311: 11-24.

ASTROF, S. and HYNES, R.O. (2009). Fibronectins in vascular morphogenesis. Angiogenesis 12: 165-175.

ASTROF, S., KIRBY, A., LINDBLAD-TOH, K., DALY, M. and HYNES, R.O. (2007b). Heart development in fibronectin-null mice is governed by a genetic modifier on chromosome four. Mech Dev 124: 551-558.

AVRAAMIDES, C.J., GARMY-SUSINI, B. and VARNER, J.A. (2008). Integrins in angiogenesis and lymphangiogenesis. Nat Rev Cancer 8: 604-617.

BACIU, P.C., SAONCELLA, S., LEE, S.H., DENHEZ, F., LEUTHARDT, D. and GOETINCK, P.F. (2000). Syndesmos, a protein that interacts with the cytoplasmic domain of syndecan-4, mediates cell spreading and actin cytoskeletal organization. J Cell Sci 113: 315-324.

BAJOGHLI, B., AGHAALLAEI, N., HESS, I., RODE, I., NETUSCHIL, N., TAY, B.H., VENKATESH, B., YU, J.K., KALTENBACH, S.L., HOLLAND, N.D. et al. (2009). Evolution of genetic networks underlying the emergence of thymopoiesis in vertebrates. Cell 138: 186-197.

BALLARD, V.L., SHARMA, A., DUIGNAN, I., HOLM, J.M., CHIN, A., CHOI, R., HAJJAR, K.A., WONG, S.C. and EDELBERG, J.M. (2006). Vascular tenascin-C regulates cardiac endothelial phenotype and neovascularization. FASEB J 20: 717-719.

BALZA, E., SASSI, F., VENTURA, E., PARODI, A., FOSSATI, S., BLALOCK, W., CARNEMOLLA, B., CASTELLANI, P., ZARDI, L. and BORSI, L. (2009). A novel human fibronectin cryptic sequence unmasked by the insertion of the angiogenesisassociated extra type III domain B. Int J Cancer 125: 751-758.

BAZIGOU, E., XIE, S., CHEN, C., WESTON, A., MIURA, N., SOROKIN, L., ADAMS R., MURO, A.F., SHEPPARD, D. and MAKINEN, T. (2009). Integrin-alpha9 is required for fibronectin matrix assembly during lymphatic valve morphogenesis. Dev Cell 17: 175-186. 
BENCHARIT, S., CUI, C.B., SIDDIQUI, A., HOWARD-WILLIAMS, E.L., SONDEK, J., ZUOBI-HASONA, K. and AUKHIL, I. (2007). Structural insights into fibronectin type III domain-mediated signaling. J Mol Biol 367: 303-309.

BENTLEY, A.A. and ADAMS, J.C. (2010). The evolution of thrombospondins and their ligand-binding activities. Mol Biol Evol 27: 2187-2197.

BENTLEY, K., GERHARDT, H. and BATES, P.A. (2008). Agent-based simulation of notch-mediated tip cell selection in angiogenic sprout initialisation. $J$ Theor Biol 250: 25-36.

BERNDT, A., KOLLNER, R., RICHTER, P., FRANZ, M., VOIGT, A., BORSI, L., GIAVAZZI, R., NERI, D. and KOSMEHL, H. (2010). A comparative analysis of oncofetal fibronectin and tenascin-C incorporation in tumour vessels using human recombinant SIP format antibodies. Histochem Cell Biol 133: 467-475.

BETZ, P., NERLICH, A., TUBEL, J., PENNING, R. and EISENMENGER, W. (1993). Localization of tenascin in human skin wounds - an immunohistochemical study. Int J Legal Med 105: 325-328.

BOURDON, M.A., WIKSTRAND, C.J., FURTHMAYR, H., MATTHEWS, T.J. and BIGNER, D.D. (1983). Human glioma-mesenchymal extracellular matrix antigen defined by monoclonal antibody. Cancer Res 43: 2796-2805.

CALVO, A., CATENA, R., NOBLE, M.S., CARBOTT, D., GIL-BAZO, I., GONZALEZMORENO, O., HUH, J.I., SHARP, R., QIU, T.H., ANVER, M.R. et al. (2008). Identification of VEGF-regulated genes associated with increased lung metastatic potential: functional involvement of tenascin- $\mathrm{C}$ in tumor growth and lung metastasis. Oncogene 27: 5373-5384.

CANFIELD, A.E. and SCHOR, A.M. (1995). Evidence that tenascin and thrombospondin-1 modulate sprouting of endothelial cells. J Cell Sci 108 (Pt 2): 797-809.

CARMELIET, P. (2000). Mechanisms of angiogenesis and arteriogenesis. Nat Med 6: 389-395.

CARNEMOLLA, B., LEPRINI, A., ALLEMANNI, G., SAGINATI, M. and ZARDI, L. (1992). The inclusion of the type III repeat ED-B in the fibronectin molecule generates conformational modifications that unmask a cryptic sequence. $J$ Biol Chem 267: 24689-24692.

CASTELLETTI, F., DONADELLI, R., BANTERLA, F., HILDEBRANDT, F., ZIPFEL, P.F., BRESIN, E., OTTO, E., SKERKA, C., RENIERI, A., TODESCHINI, M. et al. (2008). Mutations in FN1 cause glomerulopathy with fibronectin deposits. Proc Natl Acad Sci USA 105: 2538-2543.

CASTELLON, R., CABALLERO, S., HAMDI, H.K., ATILANO, S.R., AOKI, A.M., TARNUZZER, R.W., KENNEY, M.C., GRANT, M.B. and LJUBIMOV, A.V. (2002). Effects of tenascin-C on normal and diabetic retinal endothelial cells in culture. Invest Ophthalmol Vis Sci 43: 2758-2766.

CASTILLEJO-LOPEZ, C., ARIAS, W.M. and BAUMGARTNER, S. (2004). The fatlike gene of Drosophila is the true orthologue of vertebrate fat cadherins and is involved in the formation of tubular organs. J Biol Chem 279: 24034-24043.

CHAKRAVARTI, R. and ADAMS, J.C. (2006). Comparative genomics of the syndecans defines an ancestral genomic context associated with matrilins in vertebrates. BMC Genomics 7: 83.

CHIQUET-EHRISMANN, R. and CHIQUET, M. (2003). Tenascins: regulation and putative functions during pathological stress. $J$ Pathol 200: 488-499.

CHIQUET-EHRISMANN, R., KALLA, P., PEARSON, C.A., BECK, K. and CHIQUET, M. (1988). Tenascin interferes with fibronectin action. Cell 53: 383-390.

CHIQUET-EHRISMANN, R., MATSUOKA, Y., HOFER, U., SPRING, J., BERNASCONI, C. and CHIQUET, M. (1991). Tenascin variants: differential binding to fibronectin and distinct distribution in cell cultures and tissues. Cell Regul 2: 927-938.

CHIQUET, M. and FAMBROUGH, D.M. (1984). Chick myotendinous antigen. II. A novel extracellular glycoprotein complex consisting of large disulfide-linked subunits. J Cell Biol 98: 1937-1946.

CHIQUET, M., VRUCINIC-FILIPI, N., SCHENK, S., BECK, K. and CHIQUETEHRISMANN, R. (1991). Isolation of chick tenascin variants and fragments. A C-terminal heparin-binding fragment produced by cleavage of the extra domain from the largest subunit splicing variant. Eur J Biochem 199: 379-388.

CHUNG, C.Y. and ERICKSON, H.P. (1997). Glycosaminoglycans modulate fibronectin matrix assembly and are essential for matrix incorporation of tenascin-C. J Cell Sci 110 (Pt 12): 1413-1419.

CHUNG, C.Y., MURPHY-ULLRICH, J.E. and ERICKSON, H.P. (1996). Mitogenesis, cell migration, and loss of focal adhesions induced by tenascin-C interacting with its cell surface receptor, annexin II. Mol Biol Cell 7: 883-892.

CHUNG, C.Y., ZARDI, L. and ERICKSON, H.P. (1995). Binding of tenascin-C to soluble fibronectin and matrix fibrils. J Biol Chem 270: 29012-29017.

CIMA, F., PERIN, A., BURIGHEL, P. and BALLARIN, L. (2001). Morpho-functional characterization of haemocytes of the compound ascidian Botrylloides leachi (Tunicata, Ascidiacea). Acta Zool. 82: 261-274.

CLINES, G.A., MOHAMMAD, K.S., BAO, Y., STEPHENS, O.W., SUVA, L.J., SHAUGHNESSY, J.D., JR., FOX, J.W., CHIRGWIN, J.M. and GUISE, T.A. (2007). Dickkopf homolog 1 mediates endothelin-1-stimulated new bone formation. $\mathrm{Mol}$ Endocrinol 21: 486-498.

CSEH, B., FERNANDEZ-SAUZE, S., GRALL, D., SCHAUB, S., DOMA, E. and VAN OBBERGHEN-SCHILLING, E. (2010). Autocrine fibronectin directs matrix assembly and crosstalk between cell-matrix and cell-cell adhesion in vascular endothelial cells. J Cell Sci 123: 3989-3999.

CUENI, L.N., HEGYI, I., SHIN, J.W., ALBINGER-HEGYI, A., GRUBER, S., KUNSTFELD, R., MOCH, H. and DETMAR, M. (2010). Tumor lymphangiogenesis and metastasis to lymph nodes induced by cancer cell expression of podoplanin. Am J Pathol 177: 1004-1016.

DALLAS, S.L., CHEN, Q. and SIVAKUMAR, P. (2006). Dynamics of assembly and reorganization of extracellular matrix proteins. Curr Top Dev Biol 75: 1-24.

DANEN, E.H., AOTA, S., VAN KRAATS, A.A., YAMADA, K.M., RUITER, D.J. and VAN MUIJEN, G.N. (1995). Requirement for the synergy site for cell adhesion to fibronectin depends on the activation state of integrin alpha 5 beta $1 . \mathrm{J} \mathrm{Biol}$ Chem 270: 21612-21618.

DAVIDSON, B. (2007). Ciona intestinalis as a model for cardiac development. Semin Cell Dev Biol 18: 16-26.

DE LANGHE, S.P., SALA, F.G., DEL MORAL, P.M., FAIRBANKS, T.J., YAMADA, K.M., WARBURTON, D., BURNS, R.C. and BELLUSCI, S. (2005). Dickkopf-1 (DKK1) reveals that fibronectin is a major target of Wnt signaling in branching morphogenesis of the mouse embryonic lung. Dev Biol 277: 316-331.

DE WEVER, O., NGUYEN, Q.D., VAN HOORDE, L., BRACKE, M., BRUYNEEL, E., GESPACH, C. and MAREEL, M. (2004). Tenascin-C and SF/HGF produced by myofibroblasts in vitro provide convergent pro-invasive signals to human colon cancer cells through RhoA and Rac. FASEB J 18: 1016-1018.

DEGEN, M., BRELLIER, F., KAIN, R., RUIZ, C., TERRACCIANO, L., OREND, G. and CHIQUET-EHRISMANN, R. (2007). Tenascin-W is a novel marker for activated tumor stroma in low-grade human breast cancer and influences cell behavior. Cancer Res 67: 9169-9179.

DEGEN, M., BRELLIER, F., SCHENK, S., DRISCOLL, R., ZAMAN, K., STUPP, R., TORNILLO, L., TERRACCIANO, L., CHIQUET-EHRISMANN, R., RUEGG, C. et al. (2008). Tenascin-W, a new marker of cancer stroma, is elevated in sera of colon and breast cancer patients. Int J Cancer 122: 2454-2461.

DESGROSELLIER, J.S. and CHERESH, D.A. (2010). Integrins in cancer: biological implications and therapeutic opportunities. Nat Rev Cancer 10: 9-22.

DOME, B., HENDRIX, M.J., PAKU, S., TOVARI, J. and TIMAR, J. (2007). Alternative vascularization mechanisms in cancer: Pathology and therapeutic implications. Am J Pathol 170: 1-15.

DOOLITTLE, R.F. (2009). Step-by-step evolution of vertebrate blood coagulation. Cold Spring Harb Symp Quant Biol 74: 35-40.

DRUMEA-MIRANCEA, M., WESSELS, J.T., MULLER, C.A., ESSL, M., EBLE, J.A., TOLOSA, E., KOCH, M., REINHARDT, D.P., SIXT, M., SOROKIN, L. et al. (2006). Characterization of a conduit system containing laminin- 5 in the human thymus: a potential transport system for small molecules. J Cell Sci 119: 1396-1405.

DUECK, M., RIEDL, S., HINZ, U., TANDARA, A., MOLLER, P., HERFARTH, C. and FAISSNER, A. (1999). Detection of tenascin-C isoforms in colorectal mucosa, ulcerative colitis, carcinomas and liver metastases. Int J Cancer 82: 477-483.

EBNER, B., BURMESTER, T. and HANKELN, T. (2003). Globin genes are present in Ciona intestinalis. Mol Biol Evol 20: 1521-1525.

EGEBLAD, M., NAKASONE, E.S. and WERB, Z. (2010). Tumors as organs: complex tissues that interface with the entire organism. Dev Cell 18: 884-901.

ELHALLANI, S., BOISSELIER, B., PEGLION, F., ROUSSEAU, A., COLIN, C., IDBAIH, A., MARIE, Y., MOKHTARI, K., THOMAS, J.L., EICHMANN, A. et al."'(2010). A new alternative mechanism in glioblastoma vascularization: tubular vasculogenic mimicry. Brain 133: 973-982.

ERLER, J.T. and WEAVER, V.M. (2009). Three-dimensional context regulation of metastasis. Clin Exp Metastasis 26: 35-49.

EXPOSITO, J.Y., LARROUX, C., CLUZEL, C., VALCOURT, U., LETHIAS, C. and DEGNAN, B.M. (2008). Demosponge and sea anemone fibrillar collagen di- 
versity reveals the early emergence of $A / C$ clades and the maintenance of the modular structure of type $\mathrm{V} / \mathrm{XI}$ collagens from sponge to human. $\mathrm{J} \mathrm{Biol}$ Chem 283: 28226-28235.

FAISSNER, A., KRUSE, J., CHIQUET-EHRISMANN, R. and MACKIE, E. (1988). The high-molecular-weight $\mathrm{J} 1$ glycoproteins are immunochemically related to tenascin. Differentiation 37: 104-114.

FASSLER, R., SASAKI, T., TIMPL, R., CHU, M.L. and WERNER, S. (1996). Differential regulation of fibulin, tenascin- $\mathrm{C}$, and nidogen expression during wound healing of normal and glucocorticoid-treated mice. Exp Cell Res 222: 111-116.

FFRENCH-CONSTANT, C. and HYNES, R.O. (1989). Alternative splicing of fibronectin is temporally and spatially regulated in the chicken embryo. Development 106: 375-388.

FISCHER, D., CHIQUET-EHRISMANN, R., BERNASCONI, C. and CHIQUET, M. (1995). A single heparin binding region within the fibrinogen-like domain is functional in chick tenascin-C. J Biol Chem 270: 3378-3384.

FISCHER, J.W. (2007). Tenascin-C: a key molecule in graft stenosis. Cardiovasc Res 74: 335-336.

FOGELGREN, B., POLGAR, N., SZAUTER, K.M., UJFALUDI, Z., LACZKO, R., FONG, K.S. and CSISZAR, K. (2005). Cellular fibronectin binds to lysyl oxidase with high affinity and is critical for its proteolytic activation. J Biol Chem 280: 24690-24697.

FORSBERG, E., HIRSCH, E., FROHLICH, L., MEYER, M., EKBLOM, P., ASZODI, A., WERNER, S. and FASSLER, R. (1996). Skin wounds and severed nerves heal normally in mice lacking tenascin-C. Proc Natl Acad Sci USA 93: 6594-6599.

FRANCIS, S.E., GOH, K.L., HODIVALA-DILKE, K., BADER, B.L., STARK, M., DAVIDSON, D. and HYNES, R.O. (2002). Central roles of alpha5beta1 integrin and fibronectin in vascular development in mouse embryos and embryoid bodies. Arterioscler Thromb Vasc Biol 22: 927-933.

FRANCO, C.A., LIEBNER, S. and GERHARDT, H. (2009). Vascular morphogenesis: a Wnt for every vessel? Curr Opin Genet Dev 19: 476-483.

GAGGIOLI, C., HOOPER, S., HIDALGO-CARCEDO, C., GROSSE, R., MARSHALL, J.F., HARRINGTON, K. and SAHAI, E. (2007). Fibroblast-led collective invasion of carcinoma cells with differing roles for RhoGTPases in leading and following cells. Nat Cell Biol 9: 1392-1400.

GARCION, E., FAISSNER, A. and FFRENCH-CONSTANT, C. (2001). Knockout mice reveal a contribution of the extracellular matrix molecule tenascin- $C$ to neural precursor proliferation and migration. Development 128: 2485-2496.

GARMY-SUSINI, B., AVRAAMIDES, C.J., SCHMID, M.C., FOUBERT, P., ELLIES L.G., BARNES, L., FERAL, C., PAPAYANNOPOULOU, T., LOWY, A., BLAIR, S.L. et al. (2010). Integrin alpha4beta1 signaling is required for lymphangiogenesis and tumor metastasis. Cancer Res 70: 3042-3051.

GEBOES, K., EL-ZINE, M.Y., DALLE, I., EL-HADDAD, S., RUTGEERTS, P. and VAN EYKEN, P. (2001). Tenascin and strictures in inflammatory bowel disease: an immunohistochemical study. Int J Surg Pathol 9: 281-286.

GEORGE, E.L., BALDWIN, H.S. and HYNES, R.O. (1997). Fibronectins are essential for heart and blood vessel morphogenesis but are dispensable for initial specification of precursor cells. Blood 90: 3073-3081.

GEORGE, E.L., GEORGES-LABOUESSE, E.N., PATEL-KING, R.S., RAYBURN, H. and HYNES, R.O. (1993). Defects in mesoderm, neural tube and vascular development in mouse embryos lacking fibronectin. Development 119: 1079-1091.

GERHARDT, H., GOLDING, M., FRUTTIGER, M., RUHRBERG, C., LUNDKVIST, A. ABRAMSSON, A., JELTSCH, M., MITCHELL, C., ALITALO, K., SHIMA, D. et al. (2003). VEGF guides angiogenic sprouting utilizing endothelial tip cell filopodia. $J$ Cell Biol 161: 1163-1177.

GINDRE, D., PEYROL, S., RACCURT, M., SOMMER, P., LOIRE, R., GRIMAUD, J.A. and CORDIER, J.F. (1995). Fibrosing vasculitis in Wegener's granulomatosis: ultrastructural and immunohistochemical analysis of the vascular lesions. Virchows Arch 427: 385-393.

GRIMSHAW, M.J. (2007). Endothelins and hypoxia-inducible factor in cancer. Endocr Relat Cancer 14: 233-244.

GUTTERY, D.S., SHAW, J.A., LLOYD, K., PRINGLE, J.H. and WALKER, R.A. (2010). Expression of tenascin-C and its isoforms in the breast. Cancer Metastasis Rev 29: 595-606.

HASHIMOTO-UOSHIMA, M., YAN, Y.Z., SCHNEIDER, G. and AUKHIL, I. (1997). The alternatively spliced domains EIIIB and EIIIA of human fibronectin affect cell adhesion and spreading. J Cell Sci 110: 2271-2280.

HAUZENBERGER, D., OlivieR, P., GUNDERSEN, D. and RUEGG, C. (1999).
Tenascin- $C$ inhibits beta1 integrin-dependent $T$ lymphocyte adhesion to fibronectin through the binding of its fnlll 1-5 repeats to fibronectin. Eur $\mathrm{J}$ Immunol 29: 1435-1447.

HELLEMAN, J., JANSEN, M.P., RUIGROK-RITSTIER, K., VAN STAVEREN, I.L., LOOK, M.P., MEIJER-VAN GELDER, M.E., SIEUWERTS, A.M., KLIJN, J.G., SLEIJFER, S., FOEKENS, J.A. et al. (2008). Association of an extracellular matrix gene cluster with breast cancer prognosis and endocrine therapy response. Clin Cancer Res 14: 5555-5564.

HENDRIX, M.J., SEFTOR, E.A., HESS, A.R. and SEFTOR, R.E. (2003). Vasculogenic mimicry and tumour-cell plasticity: lessons from melanoma. Nat Rev Cancer 3: 411-421.

HILLEN, F. and GRIFFIOEN, A.W. (2007). Tumour vascularization: sprouting angiogenesis and beyond. Cancer Metastasis Rev 26: 489-502.

HODIVALA-DILKE, K. (2008). alphavbeta3 integrin and angiogenesis: a moody integrin in a changing environment. Curr Opin Cell Biol 20: 514-519.

HUANG, G., XIE, X., HAN, Y., FAN, L., CHEN, J., MOU, C., GUO, L., LIU, H., ZHANG Q., CHEN, S. et al. (2007). The identification of lymphocyte-like cells and lymphoidrelated genes in amphioxus indicates the twilight for the emergence of adaptive immune system. PLoS One 2: e206.

HUANG, G., ZHANG, Y., KIM, B., GE, G., ANNIS, D.S., MOSHER, D.F. and GREENSPAN, D.S. (2009). Fibronectin binds and enhances the activity of bone morphogenetic protein 1. J Biol Chem 284: 25879-25888.

HUANG, W., CHIQUET-EHRISMANN, R., MOYANO, J.V., GARCIA-PARDO, A and OREND, G. (2001). Interference of tenascin-C with syndecan-4 binding to fibronectin blocks cell adhesion and stimulates tumor cell proliferation. Cancer Res 61: 8586-8594.

HUANG, X.Z., WU, J.F., FERRANDO, R., LEE, J.H., WANG, Y.L., FARESE, R.V., JR. and SHEPPARD, D. (2000). Fatal bilateral chylothorax in mice lacking the integrin alpha9beta1. Mol Cell Biol 20: 5208-5215.

HUIJBERS, E.J., RINGVALL, M., FEMEL, J., KALAMAJSKI, S., LUKINIUS, A. ABRINK, M., HELLMAN, L. and OLSSON, A.K. (2010). Vaccination against the extra domain-B of fibronectin as a novel tumor therapy. FASEB J. 24: 4535-4544

HUMPHRIES, J.D., BYRON, A. and HUMPHRIES, M.J. (2006). Integrin ligands at a glance. J Cell Sci 119: 3901-3903.

HUVENEERS, S., TRUONG, H., FASSLER, R., SONNENBERG, A. and DANEN E.H. (2008). Binding of soluble fibronectin to integrin alpha5 beta1 - link to focal adhesion redistribution and contractile shape. J Cell Sci 121: 2452-2462.

HYNES, R.O. (2007). Cell-matrix adhesion in vascular development. J Thromb Haemost 5 Suppl 1: 32-40.

HYNES, R.O. (2009). The extracellular matrix: not just pretty fibrils. Science 326 : 1216-1219.

INGBER, D.E. (2002). Mechanical signaling and the cellular response to extracellular matrix in angiogenesis and cardiovascular physiology. Circ Res 91: 877-887.

INGHAM, K.C., BREW, S.A. and ERICKSON, H.P. (2004). Localization of a cryptic binding site for tenascin on fibronectin. J Biol Chem 279: 28132-28135.

JALLO, G.I., FRIEDLANDER, D.R., KELLY, P.J., WISOFF, J.H., GRUMET, M. and ZAGZAG, D. (1997). Tenascin-C expression in the cyst wall and fluid of human brain tumors correlates with angiogenesis. Neurosurgery 41: 1052-1059.

JIANG, B., LIOU, G.I., BEHZADIAN, M.A. and CALDWELL, R.B. (1994). Astrocytes modulate retinal vasculogenesis: effects on fibronectin expression. J Cell Sci 107: 2499-2508.

KAARIAINEN, E., NUMMELA, P., SOIKKELI, J., YIN, M., LUKK, M., JAHKOLA, T., VIROLAINEN, S., ORA, A., UKKONEN, E., SAKSELA, O. et al. (2006). Switch to an invasive growth phase in melanoma is associated with tenascin-C, fibronectin, and procollagen-I forming specific channel structures for invasion. J Pathol 210 181-191.

KASPAR, M., ZARDI, L. and NERI, D. (2006). Fibronectin as target for tumor therapy Int J Cancer 118: 1331-1339.

KAWASHIMA, T., KAWASHIMA, S., TANAKA, C., MURAI, M., YONEDA, M., PUTNAM, N.H., ROKHSAR, D.S., KANEHISA, M., SATOH, N. and WADA, H. (2009). Domain shuffling and the evolution of vertebrates. Genome Res 19: 1393-1403

KII, I., NISHIYAMA, T., LI, M., MATSUMOTO, K., SAITO, M., AMIZUKA, N. and KUDO, A. (2010). Incorporation of tenascin-C into the extracellular matrix by periostin underlies an extracellular meshwork architecture. J Biol Chem 285: 2028-2039.

KINSELLA, M.G., FISCHER, J.W., MASON, D.P. and WIGHT, T.N. (2000). Retrovirally 
mediated expression of decorin by macrovascular endothelial cells. Effects on cellular migration and fibronectin fibrillogenesis in vitro. JBiol Chem275: 13924-13932.

KOHAN, M., MURO, A.F., WHITE, E.S. and BERKMAN, N. (2010). EDA-containing cellular fibronectin induces fibroblast differentiation through binding to $\{$ alpha\} 4 \{beta 77 integrin receptor and MAPK/Erk 1/2-dependent signaling. FASEB J24:4503-4512.

KUCERA, T. and LAMMERT, E. (2009). Ancestral vascular tube formation and its adoption by tumors. Biol Chem 390: 985-994.

KUCERA, T., STRILIC, B., REGENER, K., SCHUBERT, M., LAUDET, V. and LAMMERT, E. (2009). Ancestral vascular lumen formation via basal cell surfaces. PLOS ONE 4: e4132.

LANGE, K., KAMMERER, M., HEGI, M.E., GROTEGUT, S., DITTMANN, A., HUANG, W., FLURI, E., YIP, G.W., GOTTE, M., RUIZ, C. et al. (2007). Endothelin receptor type B counteracts tenascin-C-induced endothelin receptor type A-dependent focal adhesion and actin stress fiber disorganization. Cancer Res 67: 6163-6173.

LANGE, K., KAMMERER, M., SAUPE, F., HEGI, M.E., GROTEGUT, S., FLURI, E. and OREND, G. (2008). Combined lysophosphatidic acid/platelet-derived growth factor signaling triggers glioma cell migration in a tenascin-C microenvironment. Cancer Res 68: 6942-6952.

LATIJNHOUWERS, M.A., BERGERS, M., VAN BERGEN, B.H., SPRUIJT, K.I., ANDRIESSEN, M.P. and SCHALKWIJK, J. (1996). Tenascin expression during wound healing in human skin. $J$ Pathol 178: 30-35.

LEGATE, K.R., MONTANEZ, E., KUDLACEK, O. and FASSLER, R. (2006). ILK, PINCH and parvin: the tIPP of integrin signalling. Nat Rev Mol Cell Biol 7: 20-31.

LEISS, M., BECKMANN, K., GIROS, A., COSTELL, M. and FASSLER, R. (2008). The role of integrin binding sites in fibronectin matrix assembly in vivo. Curr Opin Cell Biol 20: 502-507.

LIAO, Y.F., GOTWALS, P.J., KOTELIANSKY, V.E., SHEPPARD, D. and VAN DE WATER, L. (2002). The EIIIA segment of fibronectin is a ligand for integrins alpha 9beta 1 and alpha 4 beta 1 providing a novel mechanism for regulating cell adhesion by alternative splicing. J Biol Chem 277: 14467-14474.

LIGHTNER, V.A. and ERICKSON, H.P. (1990). Binding of hexabrachion (tenascin) to the extracellular matrix and substratum and its effect on cell adhesion. $J$ Cell Sci 95: 263-277.

LINDER, E., VAHERI, A., RUOSLAHTI, E. and WARTIOVAARA, J. (1975). Distribution of fibroblast surface antigen in the developing chick embryo. J Exp Med 142: 41-9.

LOKMIC, Z., LAMMERMANN, T., SIXT, M., CARDELL, S., HALLMANN, R. and SOROKIN, L. (2008). The extracellular matrix of the spleen as a potential organizer of immune cell compartments. Semin Immunol 20: 4-13.

MACKIE, E.J. (1997). Molecules in focus: tenascin-C. Int J Biochem Cell Biol 29: 1133-1137.

MACKIE, E.J., HALFTER, W. and LIVERANI, D. (1988). Induction of tenascin in healing wounds. J Cell Biol 107: 2757-2767.

MANTOVANI, A., ROMERO, P., PALUCKA, A.K. and MARINCOLA, F.M. (2008). Tumour immunity: effector response to tumour and role of the microenvironment. Lancet 371: 771-783.

MAO, Y. and SCHWARZBAUER, J.E. (2005). Fibronectin fibrillogenesis, a cell-mediated matrix assembly process. Matrix Biol 24: 389-399.

MARTINO, M.M. and HUBBELL, J.A. (2010). The 12th-14th type III repeats of fibronectin function as a highly promiscuous growth factor-binding domain. FASEB J 24:4711-4721.

MIDWOOD, K.S., MAO, Y., HSIA, H.C., VALENICK, L.V. and SCHWARZBAUER, J.E. (2006). Modulation of cell-fibronectin matrix interactions during tissue repair. $J$ Investig Dermatol Symp Proc 11: 73-78.

MIDWOOD, K.S. and OREND, G. (2009). The role of tenascin-C in tissue injury and tumorigenesis. J Cell Commun Signal 3: 287-310.

MIDWOOD, K.S. and SCHWARZBAUER, J.E. (2002). Tenascin-C modulates matrix contraction via focal adhesion kinase- and Rho-mediated signaling pathways. Mol Biol Cell 13: 3601-3613.

MIDWOOD, K.S., VALENICK, L.V., HSIA, H.C. and SCHWARZBAUER, J.E. (2004a). Coregulation of fibronectin signaling and matrix contraction by tenascin- $\mathrm{C}$ and syndecan-4. Mol Biol Cell 15: 5670-5677.

MIDWOOD, K.S., WILLIAMS, L.V. and SCHWARZBAUER, J.E. (2004b). Tissue repair and the dynamics of the extracellular matrix. Int JBiochem CellBio/36: 1031-1037.

MINN, A.J., GUPTA, G.P., SIEGEL, P.M., BOS, P.D., SHU, W., GIRI, D.D., VIALE, A., OLSHEN, A.B., GERALD, W.L. and MASSAGUE, J. (2005). Genes that mediate breast cancer metastasis to lung. Nature 436: 518-524

MITROVIC, N. and SCHACHNER, M. (1995). Detection of tenascin-C in the nervous system of the tenascin-C mutant mouse. J Neurosci Res 42: 710-717.

MIYAMOTO, S., TERAMOTO, H., GUTKIND, J.S. and YAMADA, K.M. (1996). Integrins can collaborate with growth factors for phosphorylation of receptor tyrosine kinases and MAP kinase activation: roles of integrin aggregation and occupancy of receptors. J Cell Biol 135: 1633-1642.

MOSHER, D.F., SCHAD, P.E. and VANN, J.M. (1980). Cross-linking of collagen and fibronectin by factor XIIla. Localization of participating glutaminyl residues to a tryptic fragment of fibronectin. J Biol Chem 255: 1181-1188.

MURPHY-ULLRICH, J.E., LIGHTNER, V.A., AUKHIL, I., YAN, Y.Z., ERICKSON, H.P. and HOOK, M. (1991). Focal adhesion integrity is downregulated by the alternatively spliced domain of human tenascin. J Cell Biol 115: 1127-1136.

NERI, D. and BICKNELL, R. (2005). Tumour vascular targeting. Nat Rev Cancer 5: $436-446$.

NGUYEN, A., THORIN-TRESCASES, N. and THORIN, E. (2010). Working under pressure: coronary arteries and the endothelin system. Am J Physiol Regul Integr Comp Physiol 298: R1188-1194.

OREND, G. (2005). Potential oncogenic action of tenascin-C in tumorigenesis. Int $J$ Biochem Cell Biol 37: 1066-1083.

OREND, G. and CHIQUET-EHRISMANN, R. (2006). Tenascin-C induced signaling in cancer. Cancer Lett 244: 143-163.

OREND, G., HUANG, W., OLAYIOYE, M.A., HYNES, N.E. andCHIQUET-EHRISMANN, R. (2003). Tenascin-C blocks cell-cycle progression of anchorage-dependent fibroblasts on fibronectin through inhibition of syndecan-4. Oncogene 22: 3917-3926.

PAEZ-RIBES, M., ALLEN, E., HUDOCK, J., TAKEDA, T., OKUYAMA, H., VINALS, F., INOUE, M., BERGERS, G., HANAHAN, D. and CASANOVAS, O. (2009) Antiangiogenic therapy elicits malignant progression of tumors to increased local invasion and distant metastasis. Cancer Cell 15: 220-231.

PAIK, D.C., FU, C., BHATTACHARYA, J. and TILSON, M.D. (2004). Ongoing angiogenesis in blood vessels of the abdominal aortic aneurysm. Exp Mol Med36:524-533.

PANKOV, R. and YAMADA, K.M. (2002). Fibronectin at a glance. J Cell Sci 115: 3861-3863.

PAULIS, Y.W., SOETEKOUW, P.M., VERHEUL, H.M., TJAN-HEIJNEN, V.C. and GRIFFIOEN, A.W. (2010). Signalling pathways in vasculogenic mimicry. Biochim Biophys Acta 1806: 18-28.

PEDRETTI, M., RANCIC, Z., SOlTERMANN, A., HERZOG, B.A., SCHLIEMANN, C., LACHAT, M., NERI, D. and KAUFMANN, P.A. (2010). Comparative immunohistochemical staining of atherosclerotic plaques using F16, F8 and L19: Three clinical-grade fully human antibodies. Atherosclerosis 208: 382-389.

PEDRETTI, M., SOLTERMANN, A., ARNI, S., WEDER, W., NERI, D. and HILLINGER, S. (2009). Comparative immunohistochemistry of L19 and F16 in non-small cell lung cancer and mesothelioma: two human antibodies investigated in clinical trials in patients with cancer. Lung Cancer 64: 28-33.

PETERS, J.H., CHEN, G.E. and HYNES, R.O. (1996). Fibronectin isoform distribution in the mouse. II. Differential distribution of the alternatively spliced EIIIB, EIIIA, and V segments in the adult mouse. Cell Adhes Commun 4: 127-148.

PETERS, J.H. and HYNES, R.O. (1996). Fibronectin isoform distribution in the mouse. I. The alternatively spliced EIIIB, EIIIA, and V segments show widespread codistribution in the developing mouse embryo. Cell Adhes Commun 4: 103-125.

POLLARD, J.W. (2008). Macrophages define the invasive microenvironment in breast cancer. J Leukoc Biol 84: 623-630.

PUENTE NAVAZO, M.D., VALMORI, D. and RUEGG, C. (2001). The alternatively spliced domain TnFnlll A1A2 of the extracellular matrix protein tenascin-C suppresses activation-induced $\mathrm{T}$ lymphocyte proliferation and cytokine production. J Immunol 167: 6431-6440.

PUTNAM, N.H., BUTTS, T., FERRIER, D.E., FURLONG, R.F., HELLSTEN, U., KAWASHIMA, T., ROBINSON-RECHAVI, M., SHOGUCHI, E., TERRY, A., YU, J.K. et al. (2008). The amphioxus genome and the evolution of the chordate karyotype. Nature 453: 1064-1071.

RAMOS, D.M., CHEN, B., REGEZI, J., ZARDI, L. and PYTELA, R. (1998). Tenascin$C$ matrix assembly in oral squamous cell carcinoma. Int $J$ Cancer 75: 680-687.

RICHARDS, G.S. and DEGNAN, B.M. (2009). The dawn of developmental signaling in the metazoa. Cold Spring Harb Symp Quant Biol 74: 81-90.

RIEDL, S., TANDARA, A., REINSHAGEN, M., HINZ, U., FAISSNER, A., BODEN- 
MULLER, H., BUHR, H.J., HERFARTH, C. and MOLLER, P. (2001). Serum tenascin- $\mathrm{C}$ is an indicator of inflammatory bowel disease activity. Int $J$ Colorectal Dis 16: 285-291.

RINKEVICH, Y., ROSNER, A., RABINOWITZ, C., LAPIDOT, Z., MOISEEVA, E. and RINKEVICH, B. (2010). Piwi positive cells that line the vasculature epithelium, underlie whole body regeneration in a basal chordate. Dev Biol 345: 94-104.

RIOU, J.F., SHI, D.L., CHIQUET, M. and BOUCAUT, J.C. (1990). Exogenous tenascin inhibits mesodermal cell migration during amphibian gastrulation. Dev Biol 137: 305-317.

RISAU, W. (1997). Mechanisms of angiogenesis. Nature 386: 671-674.

ROSANO, L., CIANFROCCA, R., MASI, S., SPINELLA, F., DI CASTRO, V., BIROCCIO, A., SALVATI, E., NICOTRA, M.R., NATALI, P.G. and BAGNATO, A. (2009). Beta-arrestin links endothelin Areceptor to beta-catenin signaling to induce ovarian cancer cell invasion and metastasis. Proc Natl Acad Sci USA 106: 2806-2811.

ROSANO, L., VARMI, M., SALANI, D., DI CASTRO, V., SPINELLA, F., NATALI, P.G. and BAGNATO, A. (2001). Endothelin-1 induces tumor proteinase activation and invasiveness of ovarian carcinoma cells. Cancer Res 61: 8340-8346.

ROTH-KLEINER, M., HIRSCH, E. and SCHITTNY, J.C. (2004). Fetal lungs of tenascin-C-deficient mice grow well, but branch poorly in organ culture. $A m ~ J$ Respir Cell Mol Biol 30: 360-366.

ROY, S., CAGLIERO, E. and LORENZI, M. (1996). Fibronectin overexpression in retinal microvessels of patients with diabetes. Invest Ophthalmol Vis Sci 37: 258-266.

RUIZ, C., HUANG, W., HEGI, M.E., LANGE, K., HAMOU, M.F., FLURI, E., OAKELEY, E.J., CHIQUET-EHRISMANN, R. and OREND, G. (2004). Growth promoting signaling by tenascin-C [corrected]. Cancer Res 64: 7377-7385.

RUPERT, E.E. and CARLE, K.J. (1983). Morphology of metazoan circulatory systems. Zoomorphology 103: 193-208.

SAGA, Y., YAGI, T., IKAWA, Y., SAKAKURA, T. and AIZAWA, S. (1992). Mice develop normally without tenascin. Genes Dev 6: 1821-1831.

SCHENK, S., CHIQUET-EHRISMANN, R. andBATTEGAY, E.J. (1999). The fibrinogen globe of tenascin-C promotes basic fibroblast growth factor-induced endothelial cell elongation. Mol Biol Cell 10: 2933-2943.

SCHLIEMANN, C. and NERI, D. (2010). Antibody-based vascular tumor targeting. Recent Results Cancer Res 180: 201-216.

SEBE-PEDROS, A., ROGER, A.J., LANG, F.B., KING, N. and RUIZ-TRILLO, I. (2010). Ancient origin of the integrin-mediated adhesion and signaling machinery. Proc Natl Acad Sci USA 107: 10142-10147.

SHIELDS, J.D., KOURTIS, I.C., TOMEI, A.A., ROBERTS, J.M. and SWARTZ, M.A. (2010). Induction of lymphoidlike stroma and immune escape by tumors that express the chemokine CCL21. Science 328: 749-752.

SINGH, P., CARRAHER, C. and SCHWARZBAUER, J.E. (2010). Assembly of Fibronectin Extracellular Matrix. Annu Rev Cell Dev Biol 26: 397-419.

SIRI, A., KNAUPER, V., VEIRANA, N., CAOCCI, F., MURPHY, G. and ZARDI, L. (1995). Different susceptibility of small and large human tenascin-C isoforms to degradation by matrix metalloproteinases. J Biol Chem 270: 8650-8654.

SOBOCINSKI, G.P., TOY, K., BOBROWSKI, W.F., SHAW, S., ANDERSON, A.O. and KALDJIAN, E.P. (2010). Ultrastructural localization of extracellular matrix proteins of the lymph node cortex: evidence supporting the reticular network as a pathway for lymphocyte migration. BMC Immunol 11: 42.

STANCHI, F., GRASHOFF, C., NGUEMENI YONGA, C.F., GRALL, D., FASSLER, R. and VAN OBBERGHEN-SCHILLING, E. (2009). Molecular dissection of the ILK-PINCH-parvin triad reveals a fundamental role for the ILK kinase domain in the late stages of focal-adhesion maturation. J Cell Sci 122: 1800-1811.

STOCKMANN, C., DOEDENS, A., WEIDEMANN, A., ZHANG, N., TAKEDA, N., GREENBERG, J.I., CHERESH, D.A. and JOHNSON, R.S. (2008). Deletion of vascular endothelial growth factor in myeloid cells accelerates tumorigenesis. Nature 456: 814-818.
TAKAHASHI, S., LEISS, M., MOSER, M., OHASHI, T., KITAO, T., HECKMANN, D. PFEIFER, A., KESSLER, H., TAKAGI, J., ERICKSON, H.P. et al. (2007). The RGD motif in fibronectin is essential for development but dispensable for fibril assembly. J Cell Biol 178: 167-178.

TALTS, J.F., WIRL, G., DICTOR, M., MULLER, W.J. and FASSLER, R. (1999). Tenascin-C modulates tumor stroma and monocyte/macrophage recruitment but not tumor growth or metastasis in a mouse strain with spontaneous mammary cancer. J Cell Sci 112: 1855-1864.

TANAKA, K., HIRAIWA, N., HASHIMOTO, H., YAMAZAKI, Y. and KUSAKABE, M. (2004). Tenascin-C regulates angiogenesis in tumor through the regulation of vascular endothelial growth factor expression. Int J Cancer 108: 31-40.

TARASEVICIUTE, A., VINCENT, B.T., SCHEDIN, P. and JONES, P.L. Quantitative analysis of three-dimensional human mammary epithelial tissue architecture reveals a role for tenascin-C in regulating c-met function. Am J Pathol 176: 827-38.

TO, W.S. and MIDWOOD, K.S. (2010). Cryptic domains of tenascin-C differentially control fibronectin fibrillogenesis. Matrix Biol 29: 573-585.

TUCKER, R.P. (1993). The in situ localization of tenascin splice variants and thrombospondin 2 mRNA in the avian embryo. Development 117: 347-358.

TUCKER, R.P. and CHIQUET-EHRISMANN, R. (2009). Evidencefor the evolution of tenascin and fibronectin early in the chordate lineage. Int J Biochem Cell Biol 41: 424-434.

TUCKER, R.P., DRABIKOWSKI, K., HESS, J.F., FERRALLI, J., CHIQUET-EHRISMANN, R. and ADAMS, J.C. (2006). Phylogenetic analysis of the tenascin gene family: evidence of origin early in the chordate lineage. BMC Evol Biol 6: 60.

UEMURA, A., KUSUHARA, S., WIEGAND, S.J., YU, R.T. and NISHIKAWA, S. (2006). TIx acts as a proangiogenic switch by regulating extracellular assembly of fibronectin matrices in retinal astrocytes. J Clin Invest 116: 369-377.

VENTURA, E., SASSI, F., PARODI, A., BALZA, E., BORSI, L., CASTELLANI, P., CARNEMOLLA, B. and ZARDI, L. (2010). Alternative splicing of the angiogenesis associated extra-domain $B$ of fibronectin regulates the accessibility of the B-C loop of the type III repeat 8. PLoS One 5: e9145.

VOSSELER, S., MIRANCEA, N., BOHLEN, P., MUELLER, M.M. and FUSENIG, N.E. (2005). Angiogenesis inhibition by vascular endothelial growth factor receptor-2 blockade reduces stromal matrix metalloproteinase expression, normalizes stromal tissue, and reverts epithelial tumor phenotype in surface heterotransplants. Cancer Res 65: 1294-1305.

VOURET-CRAVIARI, V., BOULTER, E., GRALL, D., MATTHEWS, C. and VAN OBBERGHEN-SCHILLING, E. (2004). ILK is required for the assembly of matrixforming adhesions and capillary morphogenesis in endothelial cells. $J$ Cell Sci 117: 4559-4569.

WHITE, E.S., BARALLE, F.E. and MURO, A.F. (2008). New insights into form and function of fibronectin splice variants. $J$ Pathol 216: 1-14.

WICKI, A., LEHEMBRE, F., WICK, N., HANTUSCH, B., KERJASCHKI, D. and CHRISTOFORI, G. (2006). Tumor invasion in the absence of epithelial-mesenchymal transition: podoplanin-mediated remodeling of the actin cytoskeleton. Cancer Cell 9: 261-272.

WILSON, K.E., BARTLETT, J.M., MILLER, E.P., SMYTH, J.F., MULLEN, P., MILLER W.R. and LANGDON, S.P. (1999). Regulation and function of the extracellular matrix protein tenascin-C in ovarian cancer cell lines. Br J Cancer 80: 685-692.

WILSON, K.E., LANGDON, S.P., LESSELLS, A.M. and MILLER, W.R. (1996). Expression of the extracellular matrix protein tenascin in malignant and benign ovarian tumours. Br J Cancer 74: 999-1004.

YANG, J.T., RAYBURN, H. and HYNES, R.O. (1993). Embryonic mesodermal defects in alpha 5 integrin-deficient mice. Development 119: 1093-1105.

YOKOSAKI, Y., MATSUURA, N., HIGASHIYAMA, S., MURAKAMI, I., OBARA, M., YAMAKIDO, M., SHIGETO, N., CHEN, J. and SHEPPARD, D. (1998). Identification of the ligand binding site for the integrin alpha9 beta1 in the third fibronectin type III repeat of tenascin-C. J Biol Chem 273: 11423-11428. 


\section{Further Related Reading, published previously in the Int. J. Dev. Biol.}

Insulin-like growth factor-2 regulates early neural and cardiovascular system development in zebrafish embryos

Lori Hartnett, Catherine Glynn, Catherine M. Nolan, Maura Grealy and Lucy Byrnes

Int. J. Dev. Biol. (2010) 54: 573-583

The seminal work of Werner Risau in the study of the development of the vascular system Domenico Ribatti

Int. J. Dev. Biol. (2010) 54: 567-572

Critical growth factors and signalling pathways controlling human trophoblast invasion Martin Knöfler

Int. J. Dev. Biol. (2010) 54: 269-280

The contribution of Roberto Montesano to the study of interactions between epithelial sheets and the surrounding extracellular matrix

Domenico Ribatti

Int. J. Dev. Biol. (2010) 54: 1-6

Parallels in invasion and angiogenesis provide pivotal points for therapeutic intervention Suzanne A. Eccles

Int. J. Dev. Biol. (2004) 48: 583-598

Angiogenesis and apoptosis are cellular parameters of neoplastic progression in transgenic mouse models of tumorigenesis

G Bergers, D Hanahan and L M Coussens

Int. J. Dev. Biol. (1998) 42: 995-1002

$$
5 \text { yr ISI Impact Factor }(2010)=2.86
$$

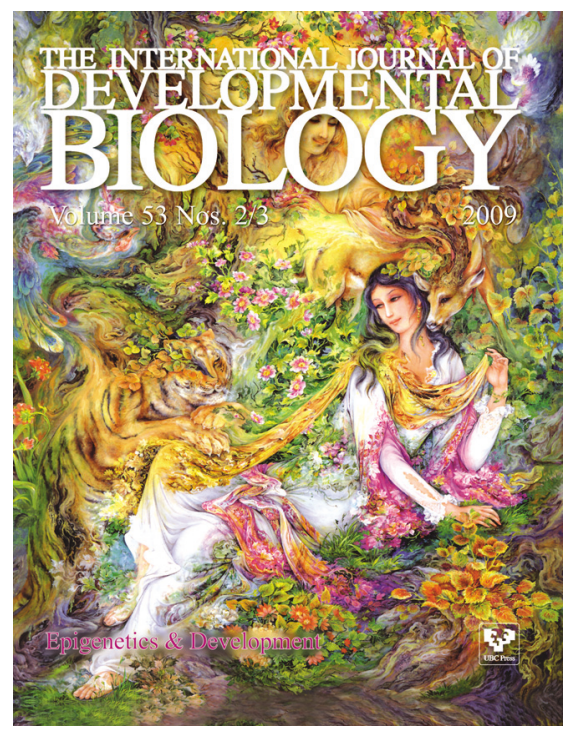

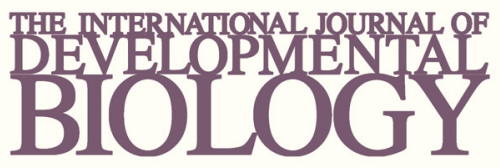

Volume 54 Nos. 6/7
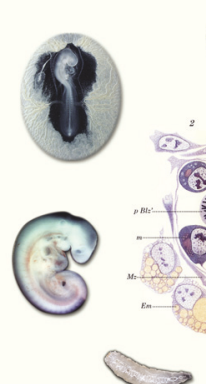

Developmental Hematopoiesis

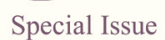

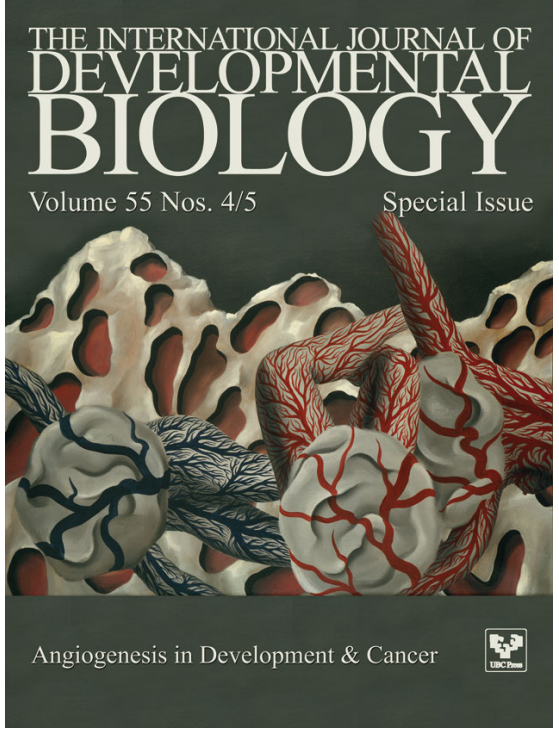

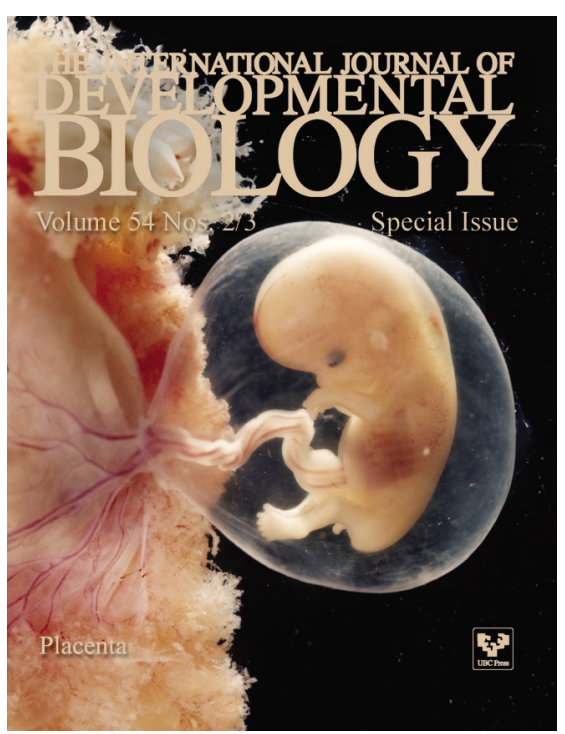

